\title{
The Pilgrims to Madrinha Dodô (Penitence and Pilgrimages)
}

\author{
Siloé Amorim
}

\begin{abstract}
Much has been said about the Beata Madrinha Dodô and her power of persuasion over the young women who joined her to be ordained as pilgrims. As the personal assistant to Padre Cícero, Dodô stayed at his side until his death. Upon meeting the beato Pedro Batista in the 1940, she became his personal assistant and moved to Santa Brígida, BA, where she cared for the beato and received the penitents. The emblematic figure of Madrinha Dodô, her relationship with Padre Cícero and Pedro Batista, who she watched die, her re-incarnation as Our Lady of Health and Our Lady of Pain, the popular Catholicism, the messianic movements of the region, the life of Dodô in the greater sertão, the faith, the trance at the curing sessions and her pilgrims are the issues addressed in this article. Theoretically and methodologically, the study uses parameters of visual ethnography and ethnography of performance to address the practice of the pilgrimage and penitence in the region where Madrinha Dodô traveled. Upon her death in 1998, she left a following of pilgrims who worship her in the region between Água Branca, Alagoas, Santa Brígida, Bahia and Juazeiro do Norte in Ceará.
\end{abstract}

Keywords: Madrinha Dodô, pilgrimages, body, cure, penitence, performance 


\title{
The Pilgrims to Madrinha Dodô
}

\author{
(Penitence and Pilgrimages)
}

\section{Siloé Amorim}

This article is part of a research project that I have been working on about Madrinha ${ }^{1}$ Dodô and the penitent pilgrim women who worship her in the region between Água Branca, Alagoas; Santa Brígida, Bahia and Juazeiro do Norte, Ceará. Throughout this region, a series of pilgrimages and acts of penitence are conducted to venerate the Beato ${ }^{2}$ Pedro Batista and the Beata Madrinha Dodô. This has occurred since the 1940s, mainly in some villages of the municipality of Água Branca, in the region known as the Alto Sertão Alagoano, like, Alto dos Coelhos, Cal, Tabuleiro, and Moreira (especially the latter, which is considered the birthplace of Madrinha Dodô).

The first contact that I had with Beata Madrinha Dodô was through plaster statues and photographs of her. I saw them placed on improvised altars where her image appeared in conjunction with saints and beatos from the region, such as Padre Cícero Romão, Frei [Firar] Damião and the Beato Pedro Batista. These images are found in the homes of rural workers in small villages and poor neighborhoods and in the houses of the Koiupanká, Kalankó, Karuazu and Katokinn, ${ }^{3}$ Indians in the Alto Sertão Alagoano, among the municipalities of Inhapi, Água Branca and Pariconha.

Two images in particular made me want to know more about the Beata Dodô. The first that I saw was during the Karuazu festival of resistance and resurgence, in 1999. ${ }^{4}$ Here I encountered an elderly, white-skinned woman, dressed completely in white, with a veil that covered her face, she had lightcolored eyes, her hands were in prayer, she was standing up in the strong

\footnotetext{
1 Translator's Note. A "Madrinha" is someone who baptizes others and is a title used to refer to people who serve as types of godmothers or protective figures.

2 Translator's Note. Beato and beata are terms that refer to a man or woman who is considered a "saint" and treated as such by people who worship him or her and follow their counsels, although this person is not necessarily recognized formally by the Catholic Church.

3 Ethnic groups that I studied from 1999 to 2009, which lead to a doctoral thesis about these Indians.

4 This particular process of indigenous resistance and resurgence in the Alto-Sertão Alagoano is part of the contemporary indigenous movements in search of ethnic affirmation and restitution, and has marked indigenous territory since colonial times.
} 
sunlight, looking towards the firmament, representing, precisely in a terreiro ${ }^{5}$ of Indigenous dance, Nossa Senhora [the Virgin Mary].The other image was found in relation to the festival of resistance of the Koiupanká Indians, which normally takes place in December of each year. Some women who were ritually dancing Toré and dressed in white, with white cloths on their head (or dressed in black, in mourning), in silence, in a type of trance, caught my attention.

I also began to notice, in some more isolated parts the region, on days of mass and in the street markets, the same image, which left me with a curious sensation: I could not stop looking at those women with those clothes. They wore simply tailored white - or light-blue cotton dresses, and had cloths of the same color tied to their heads. I later discovered that this type of clothing and its color was a reference to the "purity of Nossa Senhora."At times, during mass, one of the women (who normally kneeled or sat on the floor) would repeat the same rite of prayer and reverence, others repetitively kneeled and stood up, at times making the sign of the cross, in devotion to Nossa Senhora. ${ }^{6}$ These images, together with those of the penitents, strongly impressed me. I was not able to clearly see their relationship with the indigenous rituals. Upon observing the images of the Beata Madrinha Dodô in some homes, I did not give them much importance, but, as I conducted an ethnography of the indigenous rituals, I also sought to understand the reverence to and representation of those images. This inspired me to go to the field, particularly in 2009, to discover the meanings of those representations and understand the reverences to the Holy Cross, the indigenous promises to "enchanted" spirits and the pilgrimages to the crosses, mainly among some families of the Koiupanká, Jeripankó and Pankararu Indians. The idea for this research project was born from this understanding, and from the various times that I was in contact with the beatas and beatos of Madrinha Dodô and Pedro Batista, in Santa Brígida, Bahia. I have been undertaking the study since 2009, returning to conduct a visual ethnography of the pilgrimages

5 Translator's Note. A "terreiro" is a location where rituals are performed. In the case of the Indians the spaces are outside of their houses, in the open air and in the case of Afro-descendants they are usually inside residences.

6 This movement is part of the rituals of reverence to Nossa Senhora [the Virgin Mary], a penitence ritual that involves 70 repetitions of this movement. From field information, from the pilgrimage house and the location of the pilgrimage to Pedro Batista, Santa Brígida, BA, April 5, 2012. 
and penitence rituals in devotion to Madrinha Dodô and the beatas who worship her. In April 2012, on Holy Week, as I have done since 2009, I returned to the field (Água Branca and some villages in the Alto Sertão Alagoano and Santa Brígida), ${ }^{7}$ with students from the Anthropology course (who have been accredited in Visual Anthropology) from the Federal University at Paraíba, from Campus IV, Rio Tinto, PB, to continue the study for future publications and audiovisual productions.

\section{Theoretical and methodological considerations}

The spatial and cultural geography of the pilgrimages and penitence rituals led me to consider two particular aspects of the study that give anthropological meaning to these rituals: the sertaneja ${ }^{8}$ region between Água Branca, AL, Santa Brígida, BA and Juazeiro do Norte, CE, as I described previously, and the practice of the pilgrimages in veneration of the beatos who are canonizados as saints by the population - independently from the Catholic Church such as Padre Cícero, Pedro Batista, Frei Damião, Madrinha Dodô, Zé Vigário have been treated in the region. On many days of the year, at times in a special form, pilgrimages are organized to places associated to these people, particularly where they died or are buried.

Venerated by a large part of the sertaneja population, these unique personalities are also paid homage by the raising of statues in public squares and other places by the local government, usually donated by politicians and merchants from the municipalities or territories where the beatos lived. I also observed images of these beatos in oratories in the homes of the faithful who worship them and conduct penitence or "make promises" in search of solutions to their problems, mainly in relation to health or economic problems and those of the conscience - for "sins committed" - or simply in devotion.

The organizational direction that gives rise to these practices of pilgrimages and penitence, which are aimed at curing the body, purging the soul and at achieving a "good death," in relation to or through intermediation

7 In August 2012, the month of the anniversary of the death of Madrinha Dodô, I also returned to the field as part of the calendar that marks the rituals of devotion to these Beatos.

8 Translator's Note. The sertão is the arid interior region of the Brazilian Northeast in particular, or any backlands in general. Sertaneja is the adjective used to describe these places or their residents and culture. 
between the divine world and the human, is found in the beatas and beatos of the region, who since they were young, joined Madrinha Dodô or were led by her, initially to venerate Padre Cícero after his death in 1934, and later, to venerate Pedro Batista, after his death on November 11, 1967. Madrinha Dodô supported the pilgrimages in Santa Brígida in veneration of the priest and beato for three decades. During this period preceding her death in 1998, the beata maintained the pilgrimages organized around and nourished by moral precepts, "goodness" -help for the poor - and by faith. In this sense, a gender analysis of the case of Madrinha Dodô and her beatas, indicates an inversion of the dominant model of relations between men and women and of the religious meanings marked by gender (THEIJE, and JACOBS, apud STEIL, MARIZ and REESINK, 2003: 37-49).

It is possible to note that the number of followers of this movement, which is considered to be messianic (QUEIROZ, 1976), has been decreasing in the region, due to new religious, economic and social configurations that quickly transform the local and regional culture and society. Currently, the penitent pilgrims continue to organize pilgrimages to worship Madrinha Dodô, mainly on the anniversary of her death on August 28, but also on other dates related to her.

The flow of these pilgrimages is maintained by the symbolic elements (CASTRO, 2002) contained in the religious ideas of popular or mystical Catholicism (QUEIROZ, 1976), inculcated in the region's rural society. While these classifications are not sufficient to explain this phenomenon, it is through them that meaning is organized and attributed to the groups of beatas, pilgrims and penitents (of Dodô and Pedro Batista). Even if they come from different religions, for example, from Afro-indigenous matrixes and different territories that are far from each other.

The social organization of these groups emphasizes a set of collective representations. This system, that is, the composition, spatial distribution - and distribution of roles - the classification and inter-relations between the groups of different customs and meanings that compose these pilgrimages, guarantees the organization, the exchange of cultural values and goods (CASTRO, 2002), resistance, continuity and religious practices. In this case, this involves the values transmitted by the pilgrims, such as, for example, cure by faith, and the guarantee of "a good death," that is, "eternal peace." These aspects, distributed among the various symbolic medium, attribute, 
according to Viveiro de Castro (2002), value to the totality (of the rituals) existing in the pilgrimages and to the practice of penitence. These include "sacrifice" in order to attain grace, aspects that theoretically configure popular Catholicism and certain messianic movements, which are visible in the region through the figure of Antônio Conselheiro, ${ }^{9}$ Pedro Batista and more recently in the figure of Madrinha Dodô.

In this sense, a gender analysis of the case of Madrinha Dodô and her beatas, indicates an inversion of the dominant model of relations between men and women and of the religious meanings marked by gender (THEIJE, and JACOBS, apud STEIL, MARIZ and REESINK, 2003: 37-49). Venerated by her beatas, pilgrims and penitents in these rituals, the performatic moments directed toward her establish an hierarchized communication (LANGDON, 1996), different from that observed (to Pedro Batista and other Beatos) for the male gender, as we will see later, originating, in this way, innovations in how the performers (the beatas) of Dodô rise up to her. Adjustments are made to the ritual performances in which the structure, both social, cultural as well as messianic of popular Catholicism, is activated in these performances, in which, a religious feminine body, sacramented while still living, as in the case of Madrinha Dodô, provides spiritual support to her penitent pilgrims, specifying, as Laraia (1997), suggested, the woman as a dual being. That is, her experiences in (public) spaces are different from the male, and can be observed in her corporal postures, which are significantly different from those of the male universe (LARAIA, 1997).

\section{About Madrinha Dodô, beatos, pilgrims and penitents}

In the Alto sertão region of Alagoas, between Bahia and Pernambuco, the Beata Madrinha Dodô, as mentioned above, appears in various places represented in the oratories or small altars in the houses of the most elderly, together with images of Padre Cícero, Frei Damião and Beato Pedro Batista as part of the mosaic of Catholic saints. In addition to being a devotee, Dodô was copeira or personal assistant to Padre Cícero. ${ }^{10}$ Maria Dolores dos Santos, or Madrinha Dodô, as she

9 About the messianic movement around Antonio Conselheiro, see, for example, the classic Os Sertões by Euclides da Cunha.

10 The word used in reference to the beatas was copeira and in this context indicates the person who helps in the domestic chores in the pilgrim house: who (a) provides personal service to the beato, the 

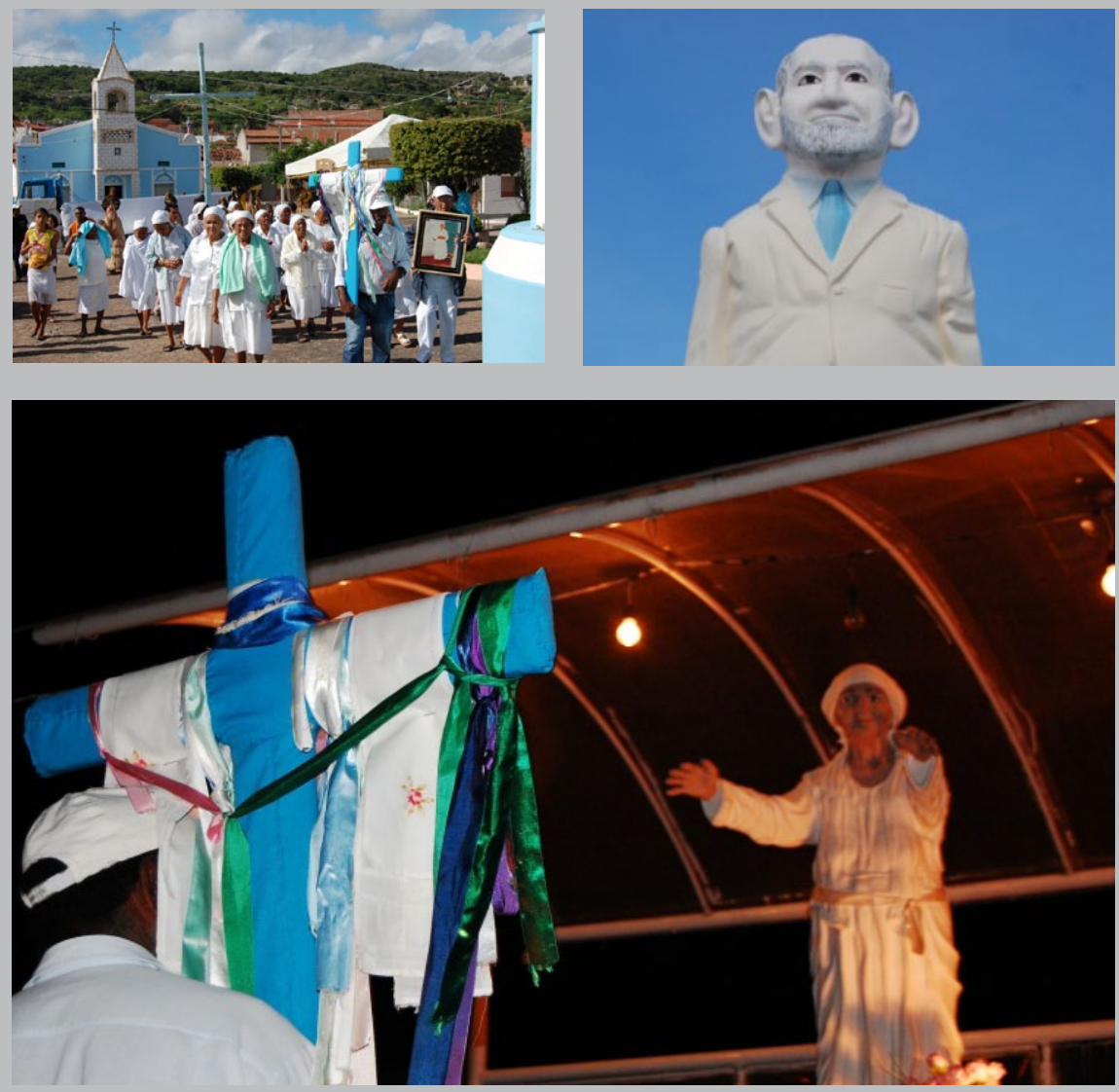

Placed in the São Pedro Square, the statutes of the beato Pedro Batista and of beata Madrinha Dodô were built to not only attract the pilgrims and penitents who worship them and Padre Cícero (who is at the base of the Cross alongside Madrinha Dodô in front of the church), but also, to create a devotional harmony in the form of occupation of the space, a direct communication between the church of São Pedro and Pedro Batista's and Madrinha Dodô's house (which serves as the lodging for the penitent pilgrims and the Museum). Those who arrive at the São Pedro Square immediately see the
Church of São Pedro (1), statute of Pedro Batista (2) and Madrinha Dodô (3) in the São Pedro Square, June 2009.

scenery that iconically relates to the beatos represented in that space.

To the rear (of Pedro Batista's house) is the lodging house for the pilgrims and penitents, which is divided into four spaces: two collective dormitory spaces (one for men and another for women, each with a bathroom), the cafeteria and the kitchen. Alongside, to the left, another room serves as a museum at which are found items, utensils and photographs, among other objects that belong 


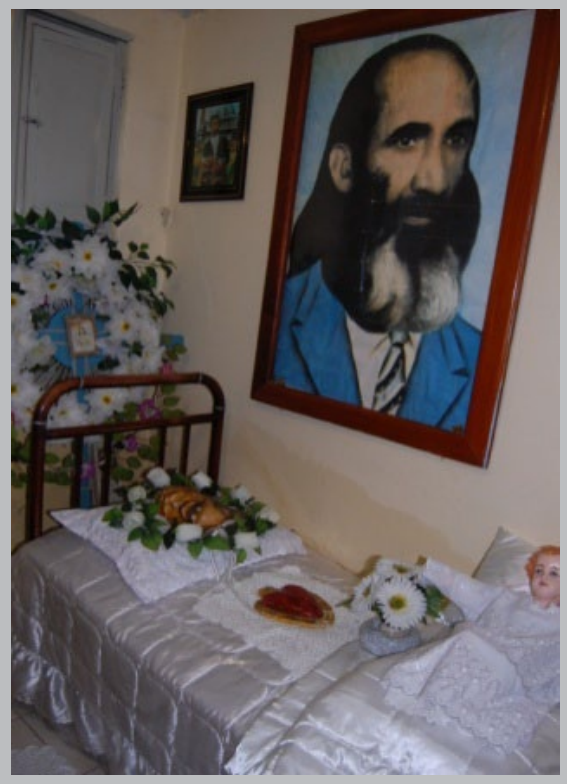

both to Pedro Batista and to Madrinha Dodô and that serve as a reference to the memory of the pilgrimages organized by the devotees, while a local guide explains the origins of some objects, indicating to whom they belonged (whether to Pedro Batista, Madrinha Dodô or other former owners), and also describes some aspects of the life of the beatos and of other people who were important in the construction of the self-image of Pedro Batista and Madrinha Dodô.

The objects and photographs documented by the organizers of the museum, and thus by the anthropologist in the field are documents that concern individual memory but that emphasize a latent collective, shared memory (RICOUEUR, 2002) referring to elements of the past-present, which today signal not only something distant in time, but that reinforce and give meaning to the pilgrimages to Santa Brígida, to the penitent-pilgrims and their peregrinations between Alagoas, Bahia and Juazeiro do Norte, CE.

In the house that was that of Pedro Batista and Madrinha Dodô lives the beata Blandina Ricardo, who came to occupy the place of Madrinha Dodô after her death in 1998 , or that is, she receives the pilgrims and penitents, cares for the house and organizes, with other beatas and assistants, the tasks related to the pilgrims' rituals. At the rear, the museum has personal objects of both, including other elements that relate to the historic process constituted since the arrival of Pedro Batista and Madrinha Dodô in Santa Brígida in the 1940s. The house, the porch, the small rooms of the beatos and the small entrance hall are occupied with personal objects: bed, clothes (even Dodô's parrots, which are still alive) and images of some saints that they worshiped and photographs of both, are spaces considered sacred, constantly visited by penitents and devotees.

The images of the saints, the photographs of Dodô and Pedro Batista, mythified by the pilgrims, indicate other codes that identify and represent different devotions and symbolic references of Mystic Popular Catholicism in the region, like the devotion to Padre Cícero, Frei Damião, Zé Vigário, a contemporary of Pedro Batista and Madrinha Dodô and other individuals who are beatified by the pilgrims. In this sense, the photographs and objects configured in this space (constructed by Pedro Batista in 1950) after his death, or, as the 


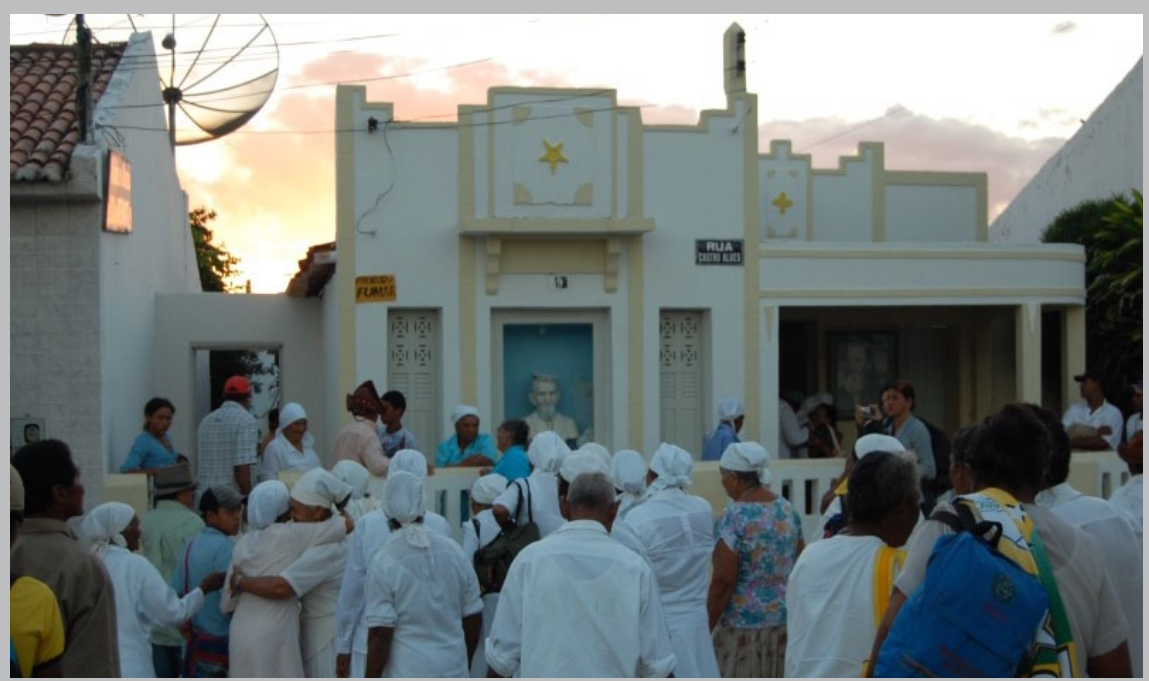

pilgrims say his "passage," the house was transformed into a sanctuary to worship them and shelter the penitent pilgrims.

These images denote, in the first place, a direct relationship with symbolic components that maintain the flow of the pilgrimages contained in the religious ideas of the brotherhoods of the groups of penitents aimed at Orthodox Christianity, that is, of medieval origin. The syncretic fusion, that is, religious appropriation of the elements of the Christian faith and of the Catholic doctrine, and of the religious aspects of the indigenous and African matrixes developed in the region, has been classified and promoted as Popular Catholicism or Mythic Catholicism. Although these classifications are not sufficient to explain this phenomenon, this is how they are organized and how the pilgrims and penitents attribute meaning to them. In this way, they resignify the images and objects of Dodô and Pedro Batista exhibited in private spaces and that
Images 1, 2, 3, 4 and 5: Upon arriving, the penitent pilgrims first go to the church, they then pay homage to the Catholic saints and the image of Madrinha Dodô inside. They then cross the square and head towards the house of Pedro Batista, at which they observe details of his bedroom, which was transformed into a museum after his death in 1967. In the background is the museum, and dormitory and cafeteria for the pilgrims. June/2009.

generate a direct approximation with the pilgrim-penitents. Juxtaposed to the "sanctified" beatos and in spaces that they had inhabited, personal objects and images become sacred in such a way that the relations between the penitents, a process of cure and other sacramented rituals are particularized through, for example, trance. This involves the spiritual reincorporation of the beatos in the present bodies of a devotee to shorten the distance between their life and death and offer a continuation to the sacred rituals in veneration of the beatos in keeping with the pilgrimages organized in the Northeast in devotion to Padre Cícero. 
is known and called, was born on Sept. 8 1902. Some people affirm that she was born in the village of Tabuleiro, others, like Dona Maria Ricardo da Conceição, her great niece and a pilgrim to Madrinha Dodô, emphatically affirm that she was born in the village of Moreira and not in Tabuleiro, which are close to each other in the municipality of Água Branca, AL. "She died on August 28, 1998, at nearly 96, in Juazeiro do Norte, although she is buried in Santa Brígida, Bahia. Dodô's transport to Santa Brígida, which some opposed, ${ }^{12}$ was intimately linked to her relationship with the Beato Pedro Batista.

Dodô, according to information from the field, "followed" Pedro Batista, at the time in which he passed through the region in the 1940s. The beata, the assistant to Beato Pedro Batista, occupied, after his death, his place as "spiritual heir and counselor" and came to be as revered as Pedro Batista himself. For the faithful in Santa Brígida and nearby, Pedro Batista is considered the "reincarnation of Padre Cícero" ${ }^{13}$ and Madrinha Dodô, is seen by some as the reincarnation of Our Lady of Suffering and, by others, as the reincarnation of Our Lady of Health, conceptions that, to not be confused as Spirist, ${ }^{14}$ are not widely promoted or commented on by the pilgrims and beatas.

priest and who takes in the pilgrims, and takes care of the kitchen, etc..

11 There are two versions about the place of birth of Madrinha Dodô: Some affirm that she was born in Tabuleiro, but others affirm that Dodô was born in Moreira. In Livro3C - Registro de Óbito no 1384, folha [sheet] 98 of Santa Brígida indicates that Dodô was born in the village of Água Branca, but does not mention the village. The villages are close to each other but differ in ethno-historical factors. For the natives, the climate, cultural, social and other differences are imperceptible to the naked eye; the microregion, composed of few houses, provides a good look at the socio-anthropological kinship relations. In most cases, the natives follow the precepts that preached or promoted the "end of the world" and the need for eternal peace. Therefore, the body must be "clean" of sins. For this reason, the undertaking of penitence and pilgrimages in search of purging, curing the body and eternal peace for the spirit, a legacy from medieval Christianity brought by the Capuchine monks during the colonial period, were followed and promoted by the beatos mentioned here. About the "Boa Morte", (RIEDL, 2007).

12 Due to the various interests of politicians, merchants and the faithful, both in Juazeiro do Norte, and in Santa Brígida, when Madinha Dodô, died, each municipality wanted the body of the beata. Because of the arguments and political power of the mayor of Santa Brígida (Rosália Rodrigues França, in 1998),Madrinha Dodô was buried in Santa Brígida, alongside Pedro Batista, a place that is now visited by pilgrims and penitents.

13 Padre Cícero Romão Batista was an important religious leader. Born in 1844 in the state of Ceará, he is considered a saint, mainly in Brazil's Northeast. He died in 1934, and became one of Brazil's main religious figures. His tomb is one of the most important points of peregrination in the country, although the Catholic Church does not recognize him as a saint.

14 It is important to clarify that, due to the precepts aimed at the religons of the African matrix, also confused with "Spiritism" or Kardecismo, the sertanejos avoid using terms like spíritas and candomblé. The sertanejos see the trance as a derivative of Shamanism. 
Based on these conceptions and for having revealed - to both male and female penitent pilgrims - "the secrets of the good death" (RIEDL, 2007), they are venerated on various occasions of the year by various groups, such as the bacamarteiros, ${ }^{15}$ that is, the group of men who represent soldiers dressed as cowhands or outlaws, which was created at the suggestion of Pedro Batista to worship São Pedro. They also represent, according to the bacamarteiros themselves, the soldiers who participated in the Paraguay War in the late $19^{\text {th }}$ century and also allude to the beato, who is said to have fought in this war. Other groups fed by the faith of Pedro Batista are the dancing, penitent devotees of São Gonçalo, rural workers and Pankararu Indians among others from the region who worship him.

Among the women pilgrims and penitents or the beatas de Madrinha Dodô, as well as the pilgrimages of penitent men, ${ }^{16}$ there are, for example, as I have said, among the Pankararu (MURA, 2012), Jeripankó and Koiupanká Indians17 rural workers, curandeiros [people who heal with herbs and prayer] and followers of the Orthodox Christian faith.18Like many others in the region, they follow special devotions to the Virgin Mary, the cult of Nosso Senhor [Our Lord] and Nossa Senhora da Boa Morte [Our Lady of the Good Death]. While the male penitents or the beatos of Pedro Batista follow the devotion of Nosso Senhor, the women follow Nossa Senhora, however there is no fixed rule for veneration. During Holy Week, for example, men and women fervently worship Nosso Senhor (who has died) and Nossa Senhora, and some rituals of this type occur in a particular manner, in which Nosso Senhor or Nossa Senhora are worshipped individually.

15 The name of the groups comes from bacamarte, which is a firearm with a long or short barrel.

16 These fraternities or sisterhoods, although they are part of the pilgrims who follow these beatos, distinguish themselves from each other in various ways, even because, the conception of each fraternity, depending on its ethnicity, social group, place, obeys its own particularities.

17 Madrinha Dodô, as I was told, "has direct kinship" with the Indians from the region: "is a legitimate cousin" of Seu João Sotero, father of the chief Zezinho Koiupank. Since Seu João is a descendent of the Pankararu Indians, of the Brejo dos Padres, Tacaratu, PE, Dodô also has relatives among the Pankararu, for which reason she is also worshiped on February 2, the day of Our Lady of Health, patron saint of Tacaratu, PE. 18 It is not the intention of this article to discuss the understanding of the canons of the Orthodox Catholic Church. While the pilgrims and penitents of Dodô and Pedro Batista obey some of the principles of the orthodox faith - like the pilgrimage, the "unconditional love for Christ watched by the Holy Spirit," the mercy for beggars, the sick and hungry - these precepts are part of the teachings of these beatos, but are also part of the culture of mercy promoted in the region to help the poor who were displaced by the drought in the sertaneja region of the Northeast in the late $19^{\text {th }}$ century. Therefore, they help people deal with these socio-political and cultural phenomenon. 
Before the image of Senhor da Boa Morte [the Lord of the Good Death] and of Nossa Senhora, the pilgrims and penitents ask for piety, purification of the soul and eternal peace. In the period preceding Holy Week, or that is, Lent, ${ }^{19}$ to elucidate this moment, the penitent pilgrims ask for purification of the sins or for a misdeed committed that offended the divine intentions, aspects that are visible on the nights of the vigils to Senhor Morto [the Dead Lord]. In these vigils, the practices of the cults of adoration of the penitents are part of the rituals of devotion to Santa Cruz [the Holy Cross] and to the "good death" and to the suffering of Nossa Senhora, mother of Jesus, for seeing her son suffer mercilessly.

These elements are represented in the cults, in the liturgical objects of these rituals and in the white or light-blue garments used by the pilgrims. In this complex scenario, the "sanctified" images of Pedro Batista and of Madrinha Dodô, who are buried in Santa Brígida, are revived and resignified by the pilgrims who arrive, mainly from Água Branca and the surroundings of Tacaratu, PE. These fraternities or sisterhoods are ordained or consecrated by the pilgrims to pay vigil to the Dead Christ, following the precepts of these beatos, and to symbolically worship them. During the pilgrimage to the cemetery, in the middle of the night from Friday to Saturday, the penitents march in silence to the tomb of Pedro Batista and Madrinha Dodô to wish them eternal peace. ${ }^{20}$

Both at the tomb of Pedro Batista and that of Madrinha Dodô, which are next to each other, the inscriptions on each of the tombstones have elements that permeate the symbolic meaning of the representations of the Virgin Mary ${ }^{21}$ and of the pilgrimages of the penitents, resignifying their post-mortum images, making each of their mausoleums a place of pilgrimage, a space of clemency and purging. These elements, transcribed in visual texts, or in our ethno-photographs, signal to us or point us to a historic view and interpretation of this process and of the orthodox and messianic precepts of Antonio Conselheiro. This happens in such a way that these images inscribed on the tombs of Dodô and of Pedro Batista allow understanding the

19 Lent refers to the 40 days that precede Holy Week. It begins on Ash Wednesday and ends on Easter Sunday on which the resurrection of Christ is commemorated.

20 Other events are programmed by pilgrims and penitents who visit the tombs of the beata and beato on various occasions.

21 Cults dedicated to the Anunciation, death, birth and purification of the Virgin Mary. 
composition of some representations and their meanings (DARBOM, apud SAMAIN, 1998:109-110) that are woven and structured in the ideals of popular Catholicism in the region (QUEIROZ, 1976), reproduced and shared as religious patrimony by Dodô, Pedro Batista and the fraternities of penitent pilgrims, beatos and beatas that they generated during their lives.

\section{The pilgrimage houses - references}

In the sertaneja region that I referred to before, as I was told, the pilgrimage houses and the fraternities of pilgrims and penitents appeared at a time in which plague and hunger uprooted the lives of thousands of people. Thousands were forced to leave their homes in the late $19^{\text {th }}$ century in the Northeast and became known as retirantes.

In the last decades of that century, in that ominous period of hunger and plague in the Northeast, the pilgrims' need for shelter, food and rest was without precedent. In relation to Dodô and her beatas and Pedro Batista and his penitents, respectively, the existence of these fraternities is due to the fact that the beata and the beato had taught "the secrets" of the supplications and dogma from the region, supplications and secrets of the Christian faith that were also transmitted to the Indians and to other followers from the small villages and isolated portions of the region, which, oppressed by the socio-historic conditions, see these figures, as "life savers." Despite the suffering caused by the poverty of that time, the suffering of the body was associated to a moral condition; therefore, to redeem the soul and put the body to rest, sacrifice, self-flagellation, peregrination, pilgrimages, supplication at the crosses and cemeteries were needed. This penitence is related to the need to ask Christ on the Cross for "a pious and painless death" and for Nossa Senhora to "intercede" in their lives, to grant "health and protection."

This aspect was observed recently during a pilgrimage on Holy Week, which left the São Pedro church in Santa Brígida. Before daybreak, the pilgrims walked barefoot, in silence to the two cemeteries in the small city: one that "of the Alagoans," at which are buried Madrinha Dodô and Pedro Batista, and the other, that of "the Bahianos." They visited the tombs of the beatos, while the master of the pilgrimage sang in a strong voice, "eternal peace." This "eternal peace" is the most sublime of the precepts aimed at the penitence to Nosso Senhor and Our Lady of the Good Death. 

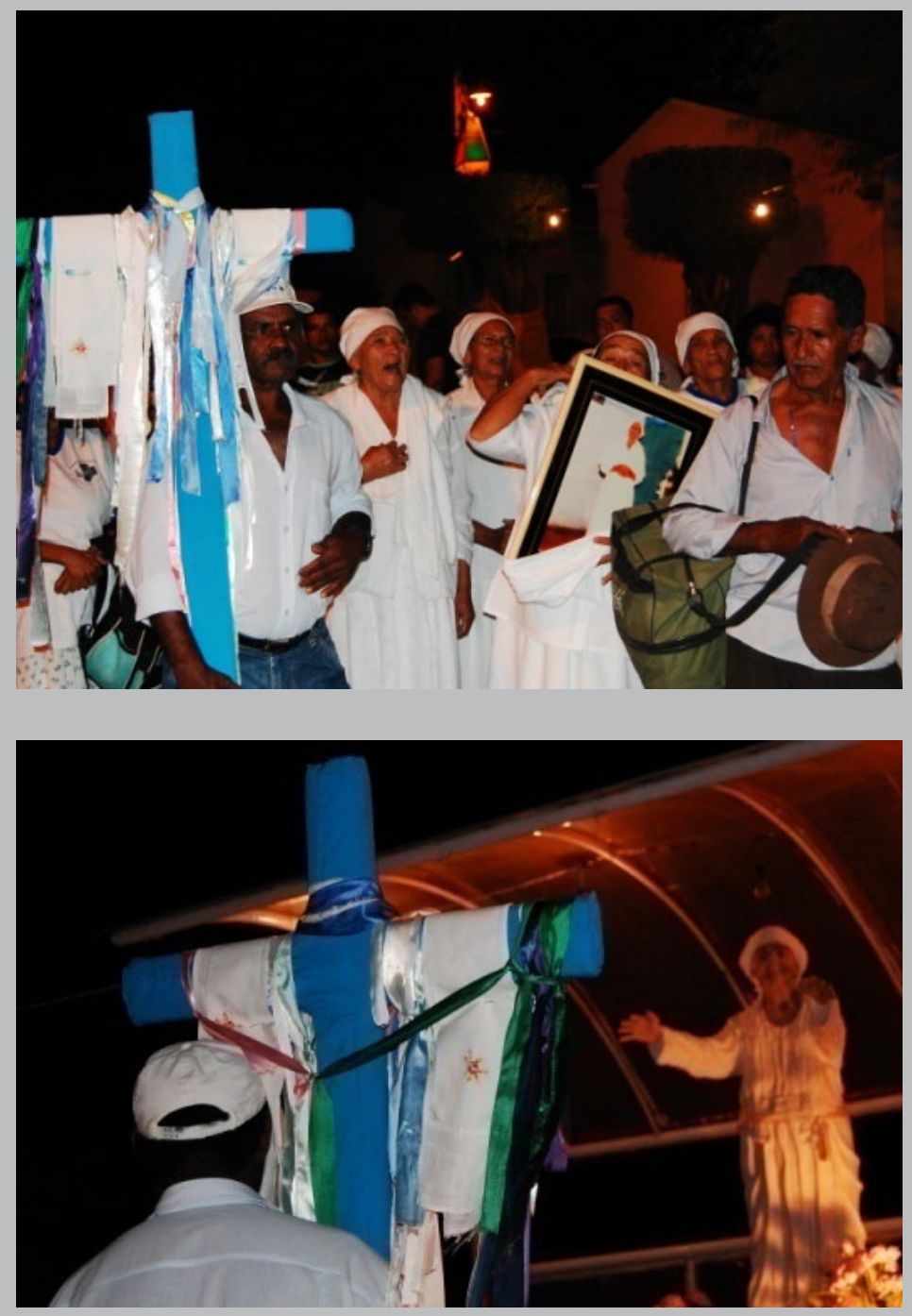

Images 6 and 7: Pilgrimages of the penitents to the statue of Madrinha Dodô. June 2009.

In this peregrination, the Holy Cross the entrance hall to the house, they pray, that the pilgrims carry is part of the penising, and depending on the penitence, or tence. At the arrival, after entering the that is, on the degree of the problem that church and praying, the group leaves and walks around the cross in front of the church three times. Then, the Holy Cross is taken in front of the image of Dodô, after worship, the cross is placed at the altar inside the house of Pedro Batista. In afflicts the individual or community, they enter - through a beata - in trance; after this moment, of some time in conversation, of expressing their problems, at times with a beata in trance, they cry, pray, chant litanies to Madrinha Dodô and are given 


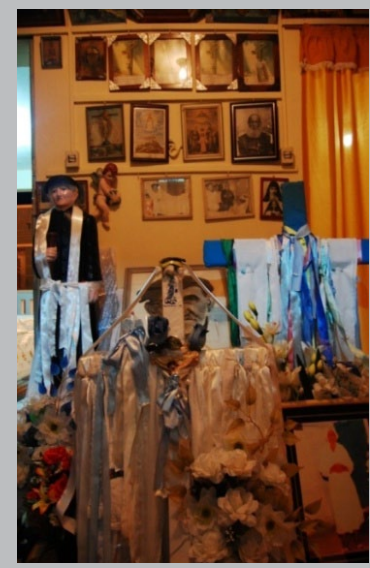

Image 8. June 2009

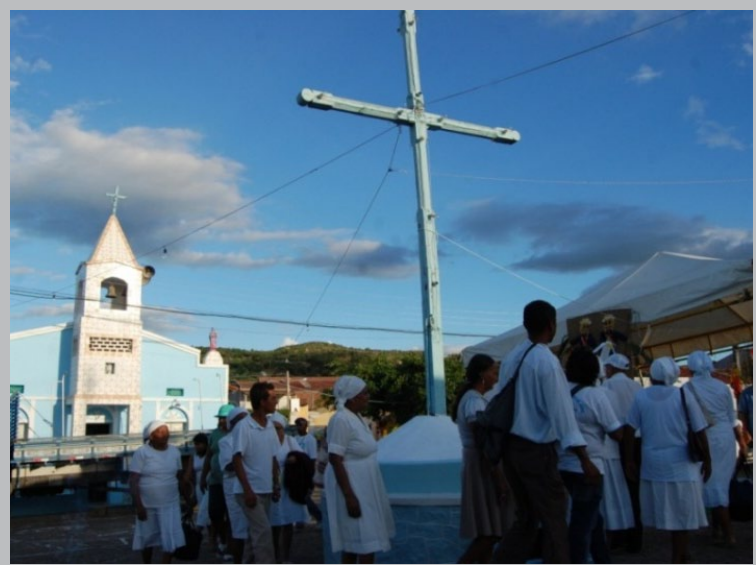

Image 9. Church of São Pedro, Santa Brígida BA, June 2009

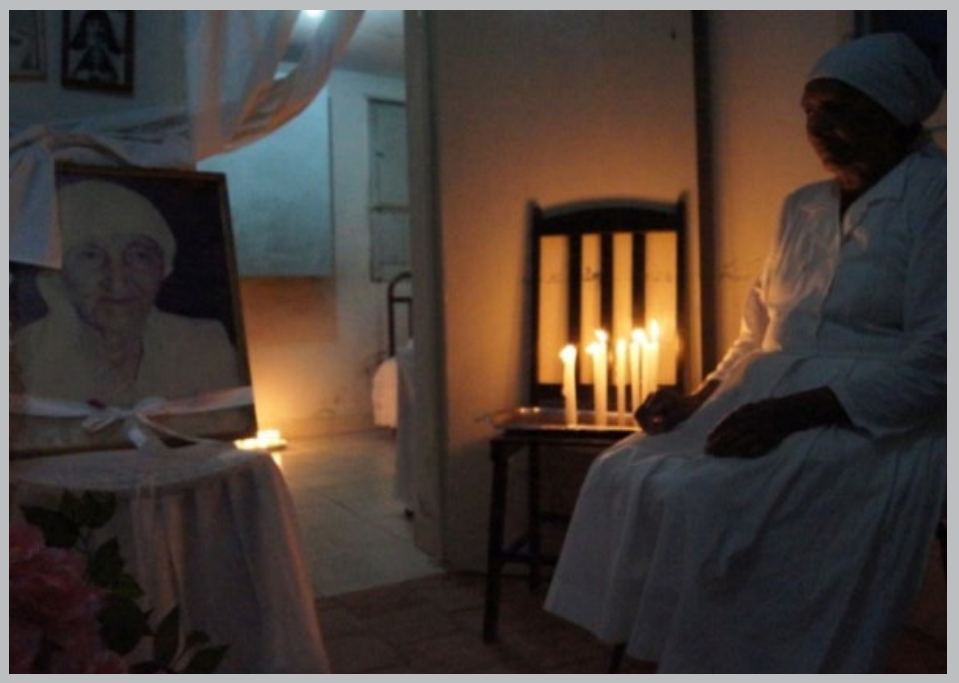

Image 10.

June 2009

In the entrance hall to Pedro Batista's house, with the door to what was his bedroom open, direct access for the pilgrims to the spaces of the sanctified beatos announces their devotion and synthesizes the effectiveness of their supernatural power over the devotees and shows details of the objects displayed on the altar to Pedro Batista and Madrinha Dodô.

Image 11. April 2012

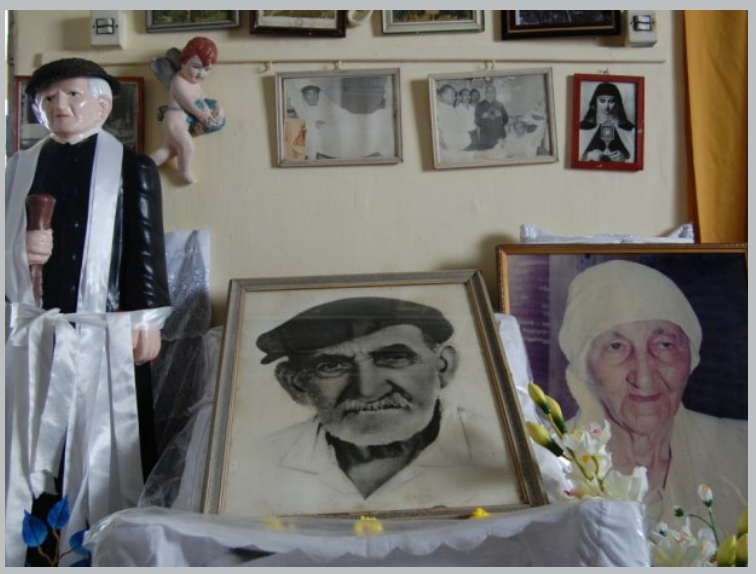


counsel, calmed down. Finally, they leave the cross at the altar - in the entrance hall to the house - and begin a process of socialization, to feed their bodies. A snack or lunch is served in the pilgrimage house. In the afternoon, once again they take the cross to the feet of Dodô (her statute in front of the pilgrimage house), and then return to the church to pay reverence to the beatos. Inside the church, they pray and sing. If the pilgrims were penitent indigenous peoples, they dance toré and conduct the entire circuit between the church, the statues of both and the house of the beatos, pray, chant songs in reverence and devotion to them and so on. Those who are not indigenous take transportation back home. Depending on the penitence, they may or may not spend the night at the house of the beatos.

The statute of Madrinha Dodô presents a unique gesture: she blesses all of the pilgrims who prostrate their bodies before her, with their heads raised, they raise their hands to meet those of Dodô. This reciprocal gesture directly communicates her blessing to the pilgrims and penitents. The images thus communicate a unique gesture of faith. These ethnophotographic narratives allow seeing the entirety and context of each gesture, thus revealing their problems, and simultaneously, the pacified souls of the penitents who sense their mission is accomplished. Thus, once again, they return to their place of origin, hoping to undertaken another penitence, in which the body demands actions to calm the soul. In this sense, men, women, children, youth and adults establish a via crucis, and, completely leave their daily universe, in an entirely popular atmosphere, pushed by a spiritual impulse, march in pilgrimages to worship their "santos beatos" and thus also purify their bodies. In the danced performances, songs, prayers and litanies, they make their human universe more plausible, collectively valuing the feminine, male, elderly, adolescent and child social universes in their

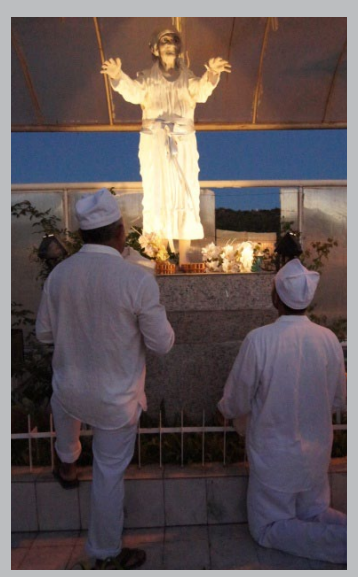

Image 12. April 2012.

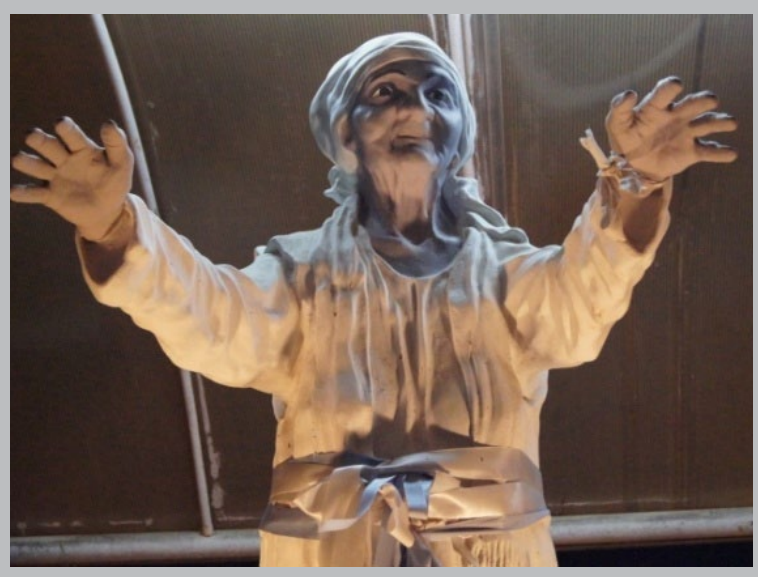

Image 13. April 2012 


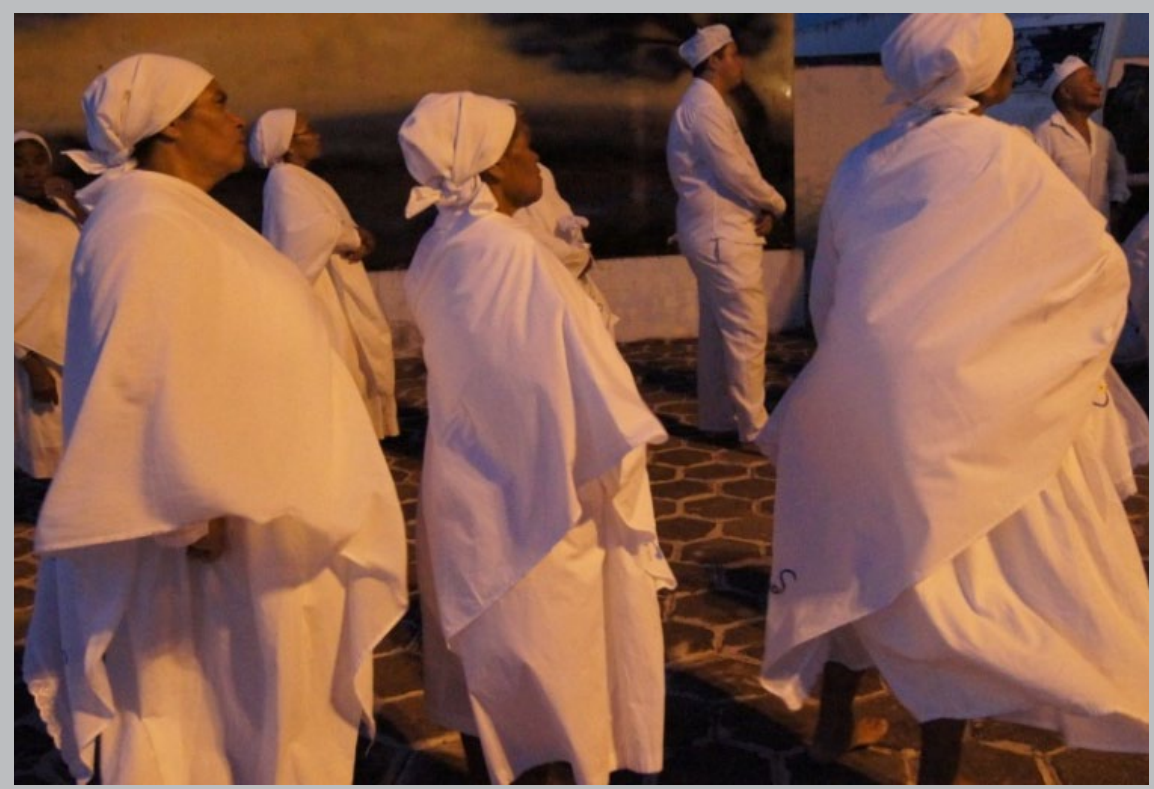

Image 14. April 2012.
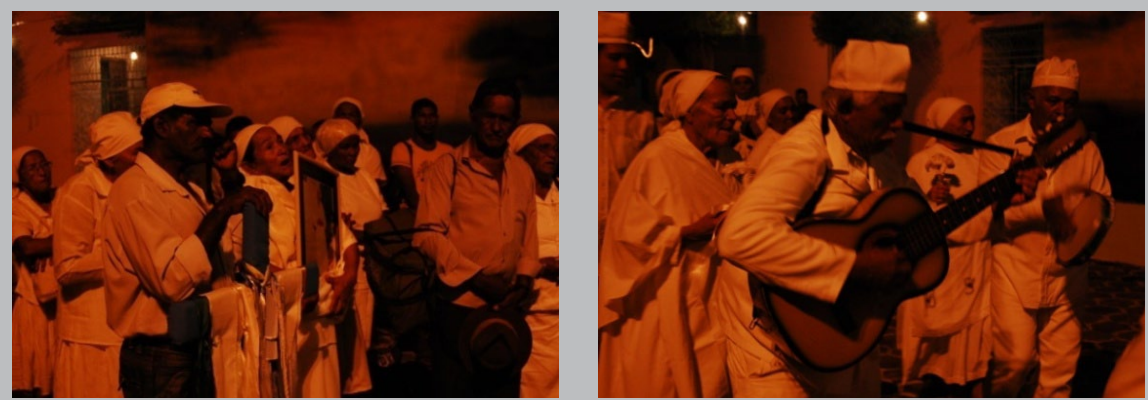

Image 15. June 2009.

Image 16. June 2009.

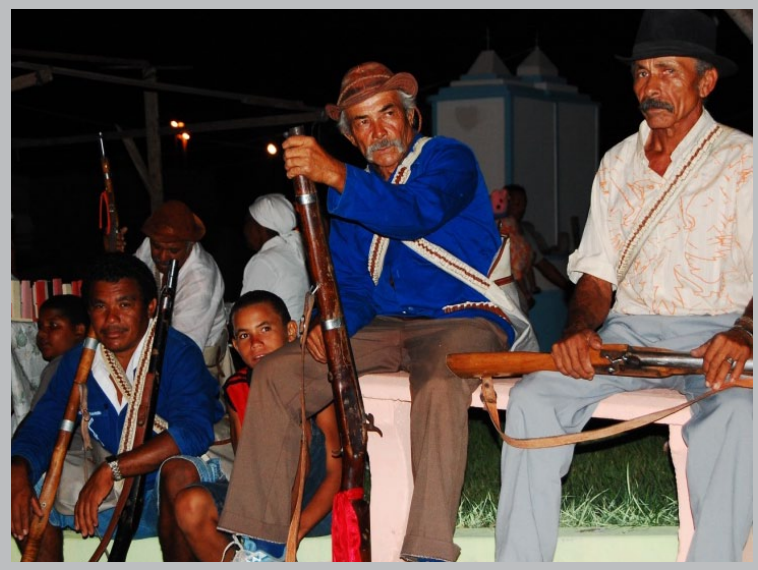

Images 14, 15 and 16: Reverence to Madrinha Dodô by the São Gonçalo (14) dancers, by the Pankararu Indians (15) and to Pedro Batista by the Grupo de bacamateiros (16) rituals previously conducted during the life of the beatos.

Image 17. June 2009. 
A very interesting study that analyzes these cults from a perspective of "cultural marketing" is that of Maíra Salles de Souza, Tereza Cristina de Oliveira and Carlota Gottchal: "Irmandade da Nossa Senhora da Boa Morte e o Marketing Cultural"[The Sisterhood of Our Lady of the Good Death and Cultural Marketing"] (SOUZA; OLIVEIRA; GOTTCHAL, 2003). The authors indicate that Our Lady of the Good Death has its origins in the early 19th century, organized by black African women. Emancipated slaves, these women secretly administered African religious ceremonies. Appropriating Catholic cults, this group of "apparently very Catholic" women simultaneously figured as "guardians of the African cults of the nagô-Yoruba Orishas from current day Nigeria. The origin of the sisterhood, according to the authors, is unknown. Located in a small house located behind the church of the Barroquinha, in Salvador, Bahia, the offices of the Sisterhood of Our Lady of the Good Death was founded in the early $19^{\text {th }}$ century.

The lack of knowledge about its origin, according to these authors, is due to the inexistence of written documentation, given that their knowledge was passed orally from generation to generation. ${ }^{22}$ These women, in their homes, had a cult to the Virgin Mary, her death and ascension in body and soul, fulfilling a promise made to the Virgin Mary for having "freed the blacks from slavery," a condition interpreted as death (SOUZA; OLIVEIRA; GOTTCHAL, 2003). Meanwhile, the Pankararu Indians and their descendants, mainly the Jeripankó and the Koiupanká, do not reveal in any way the secrets (of the good death) taught by Beata Dodô and by Pedro Batista.

It is moving to see them on pilgrimages to Juazeiro and Santa Brígida between Oct. 28 and Nov. 2 (the pilgrimage to Padre Cícero and All Soul's Day respectively).

The consensus about the Beata Dodô is that she taught curing with herbs, gave counseling and helped the poor. After the death of Beato Pedro Batista, in 1967, Dodô cared for his pilgrimage house in Santa Brígida, but did not abandon her own pilgrimage house in Juazeiro, CE. Dodô, according to data from the fieldwork, is one of the most important people after Pedro Batista.

The beatas of Dodô tell that her history began precisely with the need to venerate Our Lord and Our Lady of the Good Death, to serve the poor, the

22 The procession in reverence to the Virgin Mary in Cachoeira, BA, is known internationally. During the month of August, the ascension of the Virgin Mary with the participation of black women, emphasizing the rise of the sisterhood, is celebrated in the city. 
pilgrims and in this way, she began her pilgrimage between Alagoas, Bahia and Juazeiro do Norte. In this penitence, she would teach prayers, cures, morals, mercy and good will to those who joined her, as did Pedro Batista in his perambulations through the Sertão.

When still a girl, according to her followers, Dodô was chosen to "serve God and help the poor." Since then, she followed messianic precepts of Orthodox Christianity, first alongside Padre Cícero and soon alongside Pedro Batista, and she was the personal assistant for Padre Cícero," thus becoming both of their principle assistants. It is said that while Madrinha Dodô lived with Padre Cícero, was sent by him to baptize the newborns, which indicated great confidence and her close connection with the priest.

Upon her death in 1998, the body of Madrinha Dodô was taken from Juazeiro to Santa Brígida, for burial. A statute of Pedro Batista and another of Dodô are raised in the main square in Santa Brígida so that the pilgrims can pay reverence, an act that takes place at four periods of the year, that is: at the commemoration for São Pedro on June 28 - 29, which makes allusion to the name of the Beato (a church to São Pedro was built, one of the main churches of Santa Brígida); on August 28, the anniversary of the death of Dodô; on Sept. 15 (in Juazeiro), the day of Our Lady of Pain (the patron saint of Juazeiro);and on November 11,the anniversary of the death of Pedro Batista, in Santa Brígida. On February 2, which is the day of Our Lady of Health (from Tacaratu, $\mathrm{PE}$ ) Dodô is also worshipped by the Pankararu Indians in a large pilgrimage to Tacaratu, thus generating other readings and interpretations about the beata. The Pankararu also worship the beata on the same day that they worship Our Lady of Health.

\section{Image, performance and representation}

The representation of Madrinha Dodô as a reincarnation of Our Lady of Pain, on one hand, and on the other as Our Lady of Health by the Indians and penitents of the region, in this ritual performance (TURNER, 1974, 2005), involves, for her pilgrims, the coexistence with the traditional medieval images transmitted by popular Catholicism, which represent Our Lady, who "suffered for the pain of her child," and who was therefore "a comforting mother." In this metaphor, in the imaginary of the pilgrims and penitents of Madrinha Dodô, the beata is seen as if she was the "Virgin Mary herself" who 

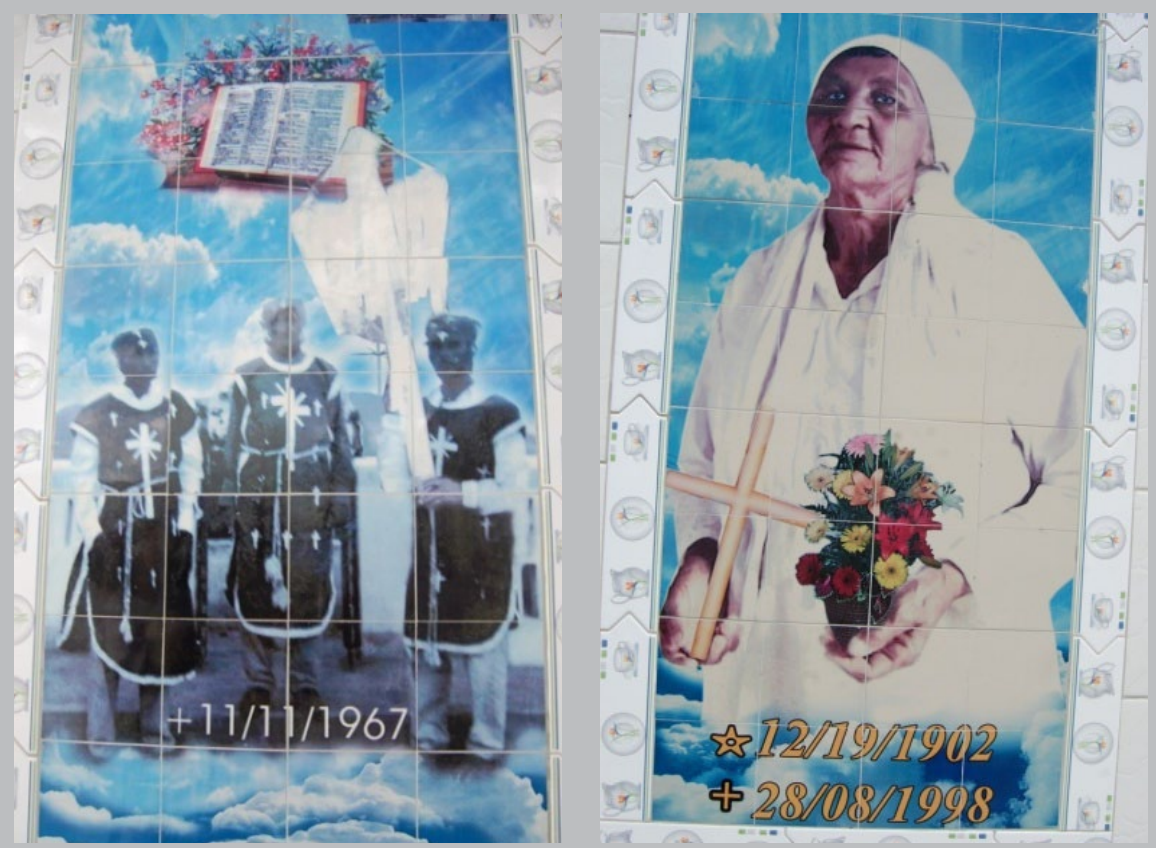

Images 18 and 19: details of the images on the tomb of Pedro Batista and Madrinha Dodô. June 2009.

devotions.

These images, as visual narratives or chronicles, stimulate considerations about the relationship of the pilgrims with Madrinha Dodô and Pedro Batista and place us before interpersonal relations between pilgrims and brotherhoods of penitent beatos. Complex by nature, they are highly synthesized in the photographic images that, in this sense, lose their illustrative character and provide the text and the readerobserver an intimate relationship between text and images, attributing meanings to the elements contained between one and another: a textual description and a visual description, whose primary resource is the look. This look that is observing and interpretative, announces, in the first place, the memory concerning the direct relationship of the penitent beatos with symbolic objects that compose the pilgrimages and their rituals, at the same time that they cultivate the organization-realization of the peregrinations contained in the religious ideas of the pilgrims and penitents of Dodô, Pedro Batista, Padre Cícero, Zé Vigário and others.

These pilgrims/peregrines organize themselves as devotees, feeding the flow of penitent pilgrims, thus giving meaning to life, an aspect that also allows them to resignify in ritual performances, through songs, litanies, curing sessions and dances, the image of Dodô and Pedro Batista, which are projected with sacred ideas - post-mortum. Some images are exhibited in public spaces, while others, photographs (private) take on analogous values due to their intimate aspects, which are also resignified by the 
group or individuals on special days for devotion to the beatos, thus feeding a close and intimate relationship with them, whether through the statutes raised in public squares or through their objects and photographs placed elegantly in spaces they inhabited during their lives, or at the gravesites adorned with motifs of their faith in the Virgin Mary and practices aimed at the penitences practiced in the Middle Ages as is seen inscribed on the tombs. In these spaces, images and objects generate a direct, immediate relationship through which pilgrims and penitents intimately approximate themselves with those they worship, asking them for good fortune and attributing supernatural powers to the beato and to the spaces they inhabited until their "trip" to beyond life.

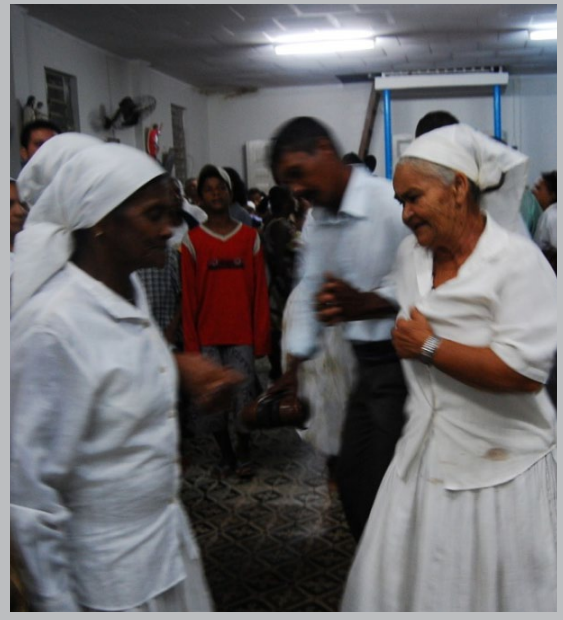

Image 20. June 2009.

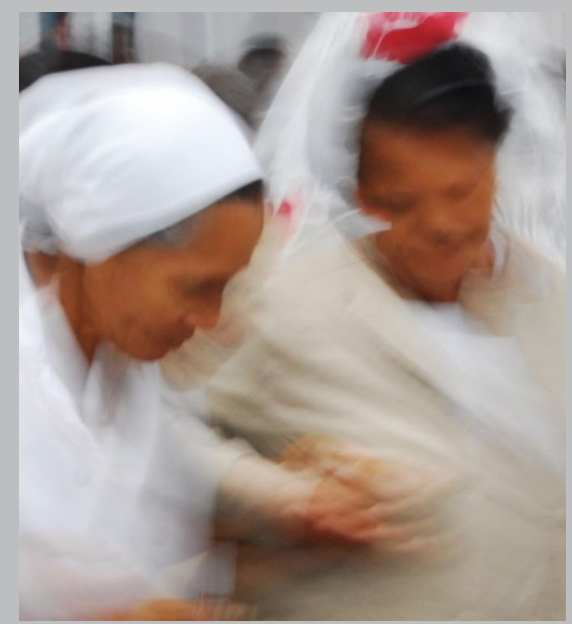

Image 21. June 2009.
Images 20 and 21: dance ritual. In this ritual, Pankararu Indians and other penitent pilgrims dance the toré in veneration to Dodô inside the São Pedro church. In the spaces designated as sacred, the relations between beatos and pilgrims, mainly between the women penitents of Dodô, become transcendent, particularized. The women, for example, enter in trance. In this sense, the photographs attest to the imagistic function of the text. These narratives or visual ethnographies inserted in the text allow multiple interpretations, guiding the observing anthropologist, and thus the reader, to an understanding of this situation. That is, the pilgrims mentioned in the text and ethno-photographed, induce the reader to a three-dimensional contemplation-interpretation unique to the image that, illustrated by the text, complements these contexts, while involving the spaces of the pilgrimages and the subjects participating in this situation. At the same time, these images place the reader before interpersonal relationships between pilgrims and beatos and the spaces that they contextualize as sacred. Finally, text and image combine and become inter-related, giving meaning to the symbolic cultural elements contained in the pilgrimages, their sacred spaces and their devotees. 

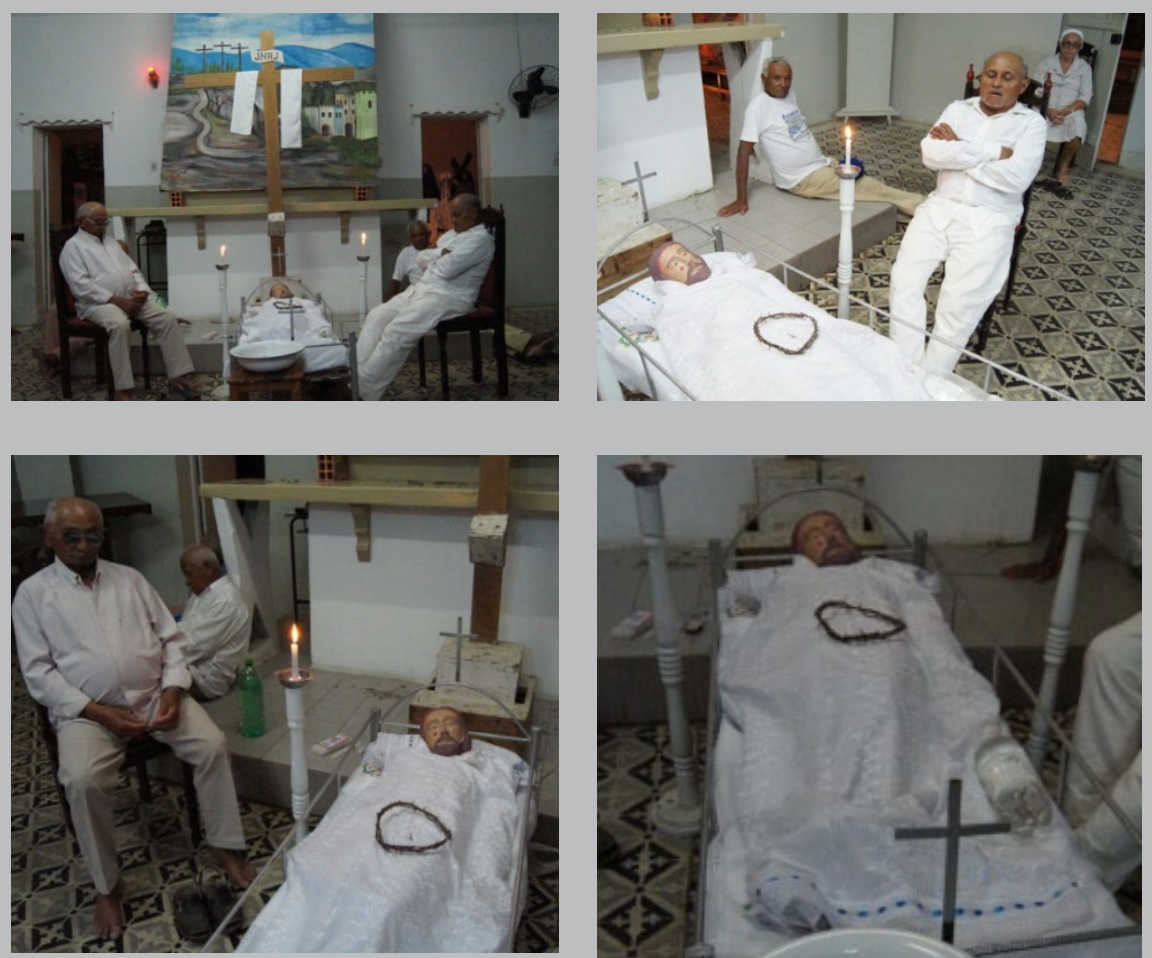

These elements can be observed in the narratives of the various performances harmonically undertaken during the Holy Week rituals, in which pilgrims and penitents performatically guide, as indicated in the

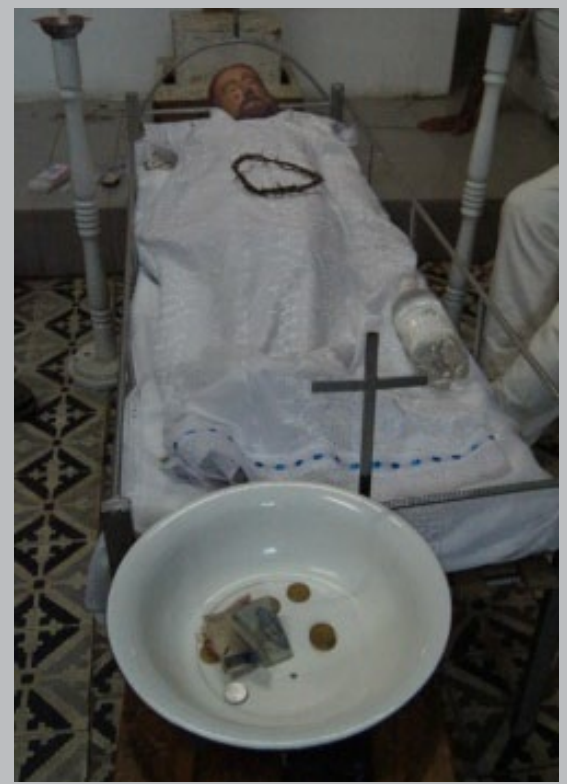

Images 22, 23, 24,25. April 2012 photographic chronicles presented here, the sociocultural contexts of the groups of pilgrims and penitents whose devotion stems from a time in which these contexts were explained through paradigms of $p o p u$ lar Catholicism, or of messianic movements, as discussed in this article. The narratives, as presented in these visual chronicles, propose, through a theoretical perspective of the image, understanding new contexts and new logics for analysis, primarily, through traditional aspects of orthodox Catholicism and also through contemporary social dichotomies of the fragmented world in which various transtemporal religious universes in transcultural contexts specify new forms of relations of human groups that organize themselves to collectively satisfy social practices. This would allow observing, in the first place, elements constituted from appropriations of traditional religious aspects of colonial or orthodox Catholicism, and secondly, other forms or cults or rituals perceived outside the common social structure and even culture of Catholicism. 


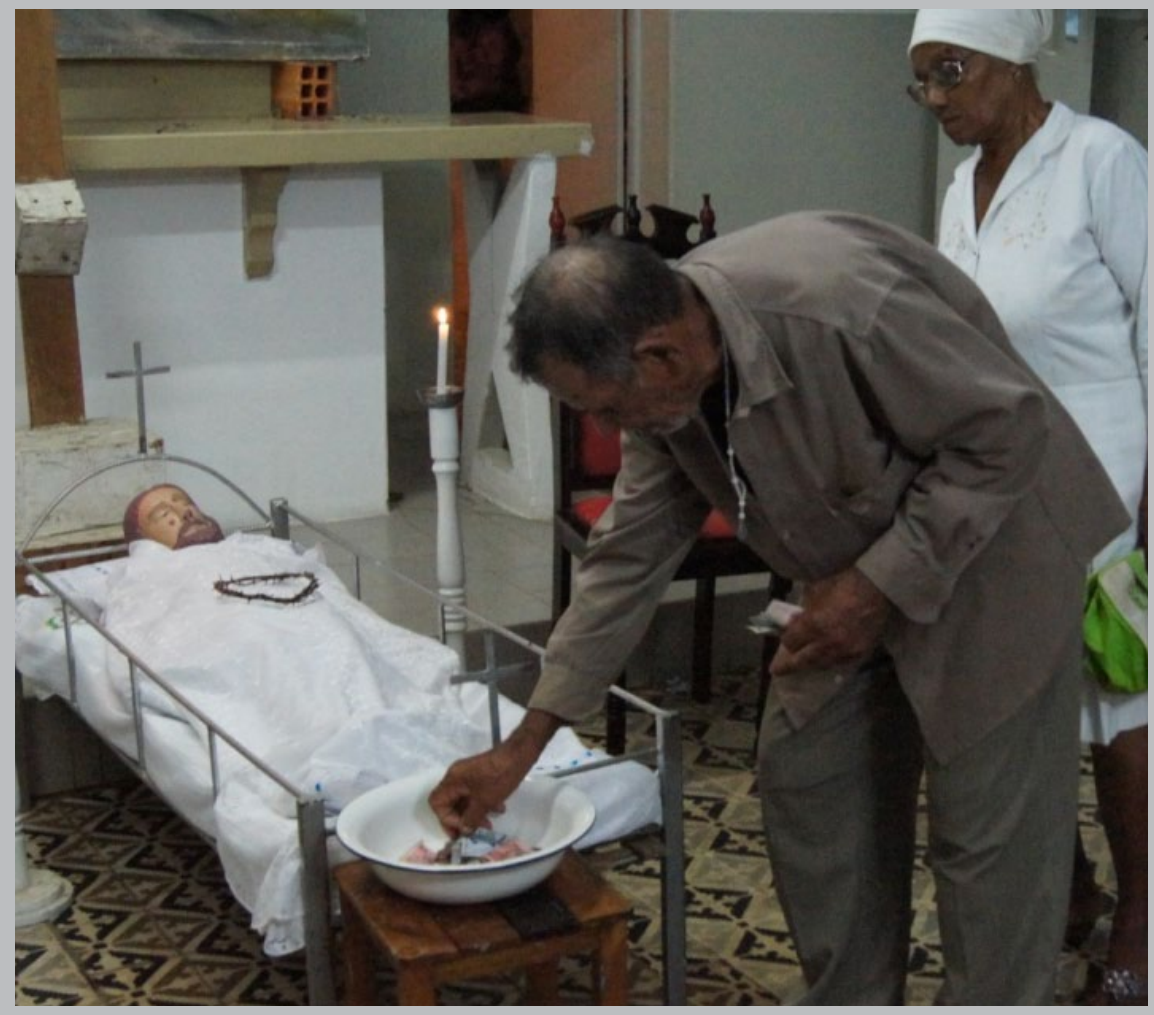

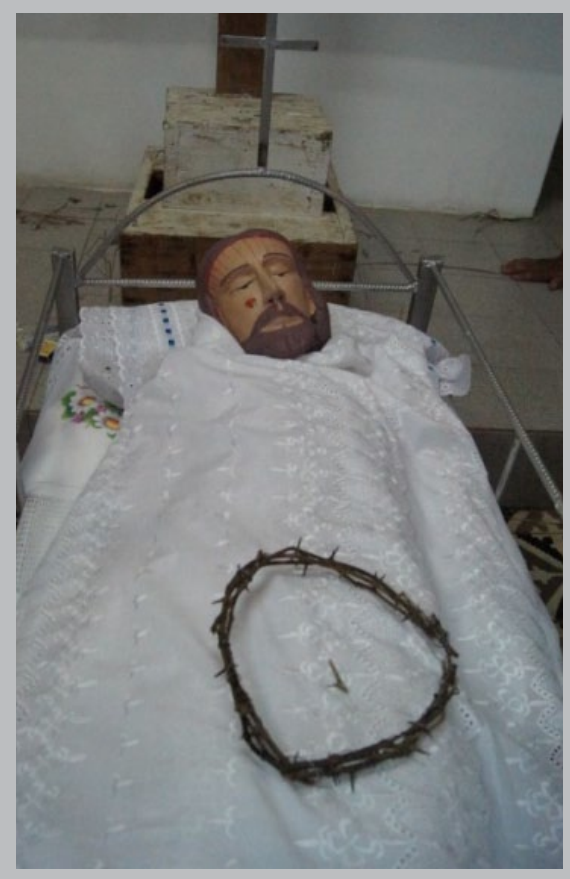

Images 26, 27. April 2012
This is what is proposed by these visual chronicles of the rituals of Easter Week in Santa Brígida, BA, in which the devotees to Madrinha Dodô and Pedro Batista - ethnophotographed penitent pilgrims - signal these characteristics that are made evident and dynamic in the rites of Easter Week and their devotion.

In this context, the devotion to the beatos (Dodô and Pedro Batista) is inter-related, making these cults and rituals dynamic. This is possible to observe in the moments in which the pilgrims and penitents intermittently visit the images of these beatos and ask for their protection, counsel and finally, during the pilgrimage to the cemeteries, ask for eternal peace from the beatos 
who have transcended from this earthly world, to a mystic Catholicized world. In this broad interpretation, the resurrection of Christ emphasizes a continuous habitation among the living, or that is, among the penitent pilgrims who see in the figure of Pedro Batista and Madrinha Dodô intermediaries to alleviate the difficulties and conflicts faced by the pilgrims and their communities.

Images 28 - 32: Groups of penitents inside the São Pedro church during the vigil to the Cristo Morto, at which they chant litanies. April 2009.
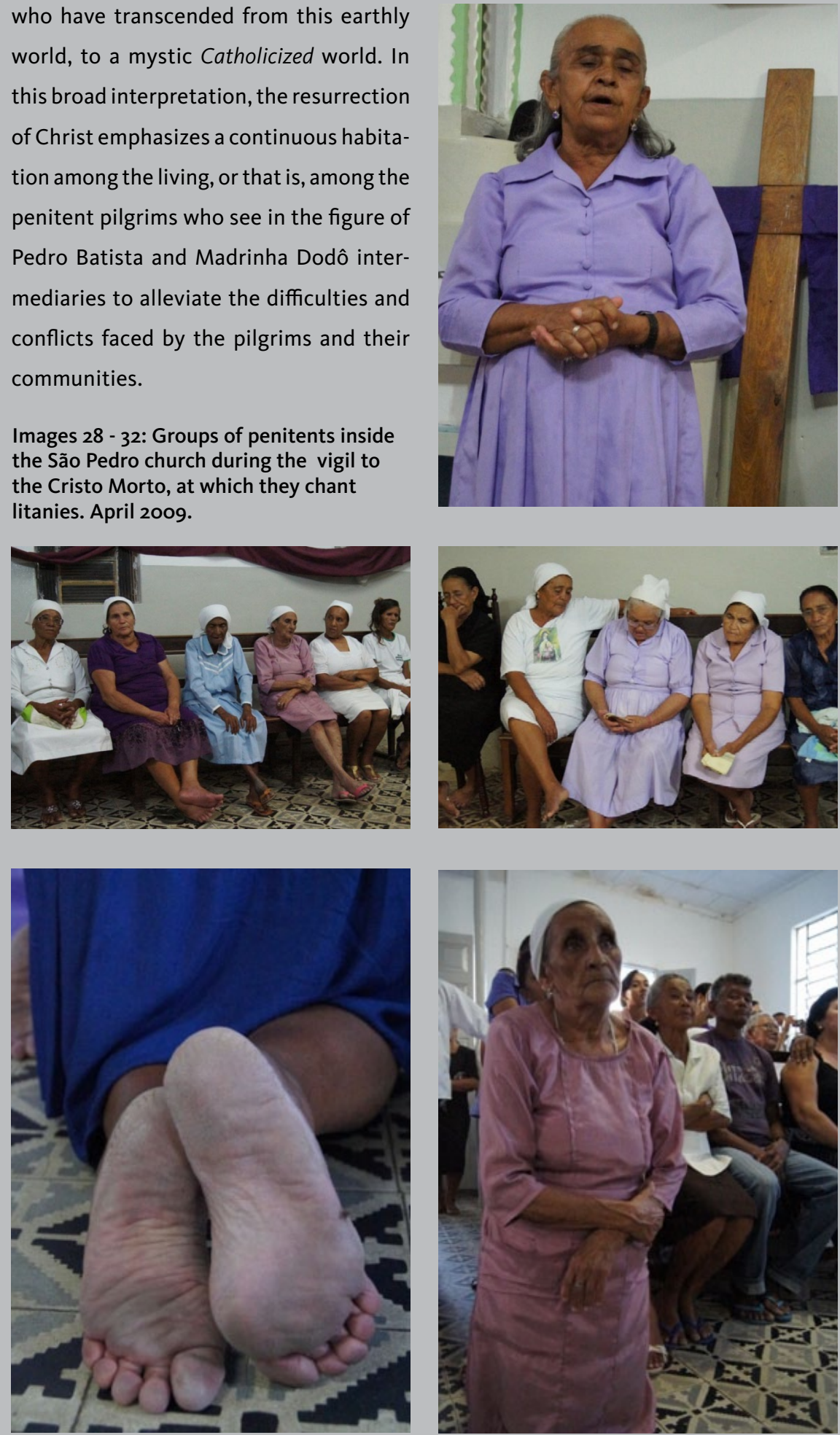
returned embodied - as Dodô - to calm and comfort her pilgrims.

This aspect is quite recurring in the pilgrimage house in Santa Brígida the Casa de Pedro Batista. In this space, the presence of the beatos, through their objects, photographs and other types of images, is quite common. Among some groups of pilgrims and peregrines, mainly those who had contact during their lives with Madrinha Dodô, when they reach the pilgrimage house, if the conflicts raised by the group of penitent pilgrims is intense, one of her beatas, Dona Maria das Virgens, enters in trance, and comforts these penitents. The trance, in the performance, the body, gesture, voice (ZOMTHOR, 1997)emphasizes the presence of Madrinha Dodô, counseling, and soothing her pilgrims. Once comforted, they are fed. The process of socialization then begins: greetings, exchanges of information about families, etc. and they soon return to their place of origin.

Before these moments and rituals, at the arrival, they undertake a pilgrimage through the São Pedro (Batista) church with chanting blessings and then pay reverence (in three short trips), ${ }^{23}$ first to the Holy Cross (in front of the church) and later to the statute of Madrinha Dodô in front of the pilgrimage house. At the entrance, they ask for the blessing from the beato, who is also represented by a statue of half his body and enter the house. In the living room - which is now a type of altar, a museum for the two - they prostrate themselves, pray and sing blessings. Some beatas or pilgrims, in trance, begin with a moving communication with Madrinha Dodô and construct through a performance known as a corpo traçado [a body in another body] - a being that is an embodiment between an earthly being (Dodô in the body of a beata) and another cosmic, supreme being (Our Lady). In this way a community is created (TURNER, 2005) that is expressed in ritual performances whose action is visible in their bodies: gestures, auditory reactions (emissions of sounds) and emotions (ZUMTHOR, 1997). These involve both the performer and those who are present, who together conjugate a single purpose: to give expression to their experiences.

This dual entity - in these personal experiences, which were ethnographed during the pilgrimages to Santa Brígida, in these encounters with Dodô, Our Lady, through a beata, in trance - establishes a conversation with the pilgrims who are sons of Maria - godchildren of Dodô, who speak with

23 These three "trips" symbolically represent the Father, the Son and the Holy Spirit. 
their Madrinha, a "mimesis" of Our Lady, about tormented events that afflicted the community or the family.

The relationship established in these performances is moving: collective weeping by the tearful penitents, fervent praying by some, dramatic looks from others who are marked by daily life, in that moment represented in the clamor for divine intervention. These factors lead us to see a worldview that is particularly sertanejo and from the Brazilian Northeast, where the subjects, through a self-understanding of themselves, of their history, of their culture (GEERTZ,2003)are juxtaposed in a Biblical moment (as at Holy Week and other similar rituals) represented in the images that configure popular Catholicism through the image of the Holy Cross, of Jesus Christ and Our Lady (always merciful), and before Our Dead Lord, who was crucified "for us." These images are disseminated in visual narratives on the walls and altars of the churches and even in the pilgrimage houses, some of the shelters that take in the penitent pilgrims.

Nevertheless, these socio-anthropological phenomena, once ethnographed and imagetically observed, lead us to other interpretive biases, (EKERT and ROCHA, 2004). These images-messages of the body, in these performances (TURNER, 1974, 2005), metaphorically cross frontiers that go beyond the verbal, to lived reality itself. These aspects of a subjective order gain veracity in these performances, given that in these ritual performances the human body is not only limited to conscious knowledge, but, according to Le Bretom (2007), is a medium for obtaining knowledge from the world and experiencing it. In this way, meanings are attributed to visible factors, that is, real factors of the world and to existence based on a symbolic system that each community experiences, which is derived from specific trajectories and experiences (EKERT E ROCHA, 2004), considering that the individual symbolically appropriates the world through his perceptions and his projections of meanings about it. The sensorial perceptions are read as personal interpretations of the universe of meanings (LE BRETON,2007) and are part of the results of the experience of the subject based on the social role to which it is located and the symbolic codes that it shares.

The action of the beatas of Dodô in the reception and organization of the events at Santa Brígida manifest the symbolic content in the rituals of veneration of the Beata. Nevertheless, in the region, the geography, or flow and organization of the pilgrimages that mark the territory between Água 
Branca, Santa Brígida, Juazeiro do Norte and Tacaratu, PE, are structured as ritual attributions aimed at various groups of pilgrims. ${ }^{24} \mathrm{Although}$ they are heterogeneous, these groups resist the contemporary problems of modernity and give continuity to these rituals of messianic veneration of orthodox Christianity. This process of resistance by the followers of Dodô and Pedro Batista is not visible in a superficial observation, it is observed precisely in the peregrinations and points or encounters of pilgrims at which the flows of this mysticism are conjugated in the individual spirituality, which, however, is expressed collectively.

The complexity that indicates these particularities, in the Northeast, contrasts with the contemporary sociocultural reality in which their adepts or organizers live, that is, the faithful themselves. These contradictions, from the perspective of an ethnographic analysis in the field of religiosity, coexist among men and women pilgrims, thus separating particularities of gender (male, female), although, in the penitential processes, the individuals of each gender strengthen their roles in the group (THEIJE and JACOBS, apude STEIL, MARIZ and REESINK, 2003: 37-49) during the pilgrimages, at the same time as they reinvigorate and reconfigure the symbolic contents that transmit meanings aimed at the pilgrimages, the penitence and the rituals that compose these moments. The social roles of men and women in the liturgy of the rituals (of cure, of penitence and the rituals of self-flagellation), which are restricted as far as we know to the male sex, are now shared, mainly concerning the spiritual powers of communication (through trance) with the beatos. At this time, the group recognizes the individual (man or woman) who interacts with this form of "direct" communication with his or her spiritual protector, an action that also takes form through the devotion of the beatos who have been "sanctified" for their "spiritual power of cure" and by faith.

This particularity, observed on these occasions, led religious scholars to relate them to popular Catholicism or to messianic movements in the Northeast, relations linked to Padre Cícero Romão and the emblematic figure of Antônio Conselheiro and his relations, whether of veneration or of persecution, with the politicians and coronels ${ }^{25}$ of the region (QUEIROZ, 1976: 294-305).

\footnotetext{
24 Like those that were already mentioned: Indians, bacamateiros, São Gonçalo dancers, and others.

25 Translator's Note. Coronel is an expression used in Brazil and particularly the Northeast to refer to people who are large landowners, political leaders or both and have considerable influence over the population through means inside and outside formal legal structures.
} 
Little is known about the private life of Pedro Batista. In the book of the obituary (no 1-4) at Santa Brígida, there is no information about his place of origin, date of birth or the name of his father, mother or grandparents. Studies about him have revealed nothing about this information. Researcher Maria Isaura Pereira de Queiroz (1976: 294), working between 1954 and 1958was not able to find this information. It is known that he peregrinated before 1942, the year in which Santa Brígida was established, through the interior of Alagoas, Sergipe and Pernambuco, preaching and curing, for which he was followed by hundreds of people. Nevertheless, essential data was registered when Pedro Batista took a loan from the Banco do Nordeste in 1955. The bank records indicate that he was born in 1888 in the municipality of Porto Calvo, Alagoas (GONZALES, 2004, p.40). ${ }^{26}$

The inhabitants and pilgrims of Santa Brígida confirmed that the beato was born in Alagoas and that his father was from the Rocha Wanderley family, which, for political reasons, fled to Pernambuco, where Pedro Batista was raised. It is consensually commented that he served in the army when he was 17, in Pernambuco, but also in Foz do Iguaçu and in Ponta Grossa, PR and participated in the persecution of the jagunços ${ }^{27}$ of the Contestado, a movement of this name that took place in the early 2oth century in Paraná and Santa Catarina, due to the violent land conflict in that region, which involved poor squatters, blacks, mestizos and indigenous peoples.

During this peregrination through the sertão, the mysterious figure of Pedro Batista, with long hair and a long, gray beard, recalled that of Antônio Conselheiro. In his wanderings, he used the same resources as Conselheiro: he offered counseling and preached morality and humility, goodness, poverty and the hope of one day "living in paradise." He passed through the region of the Pankararu Indians, by whom he was taken in. This encounter led to the devotion of the Pankararu (and their descendants) among which he left followers and devotees in the region. Each year, since the 1940s, Indians and sertanejos from the region make pilgrimages to Santa Brígida to pay reverence to the beato. Many stories and legends about his power of cure, persuasion, political power, goodness and faith are nourished among pilgrims of these

26 This document is photocopied in the work of Gonzalez (2004, p. 40). Other personal data about the life and origin of the Beato continue without clarification until now.

27 Translator's Note. A Jagunço is an armed band often contracted by coronels or land owners as hired guns. 
beatos, ${ }^{28}$ whose anonymity, mysteries of faith, spiritual power and enigmas are nourished about them by the pilgrims.

When he left the army, according to the pilgrims, Pedro Batista worked as a sailor and dock worker in the ports of Rio de Janeiro, Santos and Paranaguá, and he remained at the later location as a fisherman and farmer. In 1940, it is said that a vision led him to return to the Northeast as a peregrine until he settled in Santa Brígida, where he died, supposedly at the age of 80 (QUEIROZ, 1976: 294-304). ${ }^{29}$

Today, Santa Brígida, which before Pedro Batista, had about 30 houses, is now a municipality of more than 18,00o residents, and after his death in 1967 became an important center for pilgrimages, penitence and devotion to the Beato Pedro Batista and Beata Madrinha Dodô. ${ }^{30}$. This devotion, can be observed discretely in the Holy Week rituals in which the pilgrims secretly conduct self-flagellation.

On a few dates of the year, during Lent for example,31it is common for the penitents - a group of men who during the enactment of the via crucis should not be recognized - to use medieval costumes: cover their faces with a white cloth or hood, and use a type of navy blue or black smock that goes beyond the knees,32over a white veste (type of pants) and "flagellate themselves until they bleed," while others, those who are not flagellating themselves, chant blessings. The penitents belong to the "Order of

28 I once heard that among the Pankararu that there are groups opposed to the worship of Pedro Batista. Because he was a "a strange person with incredible persuasive power," the Beato provoked mistrust among the Pankararu, at the time he passed through, and various groups do not follow him. About Madrinha Dodô, I heard it said that the "coronels" sent her their daughters for her to watch and care for their "purity." When these virgins would go out anywhere with her, "they would walk in single file, without ever looking to the side." These and other references will be further explored, given that, until know, not a significant number of people have confirmed this data.

29 Queiroz (1976), between pages 294 and 304 reports the saga of Pedro Batista. The information that I present here, in addition to being based on Queiroz, was also the fruit of a visit that I made to Santa Brígida, on June 26 - 29, 2009, to better understand the relationship between the Kalankó, Karuazu, Koiupanká and Katokinn Indians and the Catholic promises or to the spirits understood by the Indians to be "enchanted".

30 Information from the field from June 26-29, 2009.

31 I have information that the group of penitents does not meet on fixed dates, but when they are convoked by the leader, which generates even greater "secrecy" about them, given that no one outside the group can notice them, see them. It is known, however, that on the day for São Pedro, June 28, they gather and make a visit to the tomb of Pedro Batista.

32 The tomb of Pedro Batista has this image inscribed on the stones, representing his affiliation to the brotherhood of the penitents. 
Beatos" and conduct self-flagellation to "purify the sins of the flesh." In their peregrinations, when they enact the passion play, on the days before Lent, on Holy Week, they carry Christ's cross, which they call the "Holy Cross." During the pilgrimages and penitences, the beatas, "ordained" by Dodô-many of whom abandoned the idea of marriage and are dedicated to cure and to caring for the pilgrims and the ill -care for the food, offer blessings and participate in the liturgy aimed at Our Lord and Our Lady of the Good Death. This also takes place at the pilgrimages in devotion to Pedro Batista and Madrinha Dodô.

\section{The references}

It was not by chance that Colonial Brazil was called the land of the "Holy Cross." During this period, the passion and death of Jesus Christ were remembered and reenacted at all the places dominated by the colonizers, for a "single" purpose: to induce and impose the Christian faith on the natives.

Since then, the rural people, the religious and the "new faithful" invoke God, in "The Name of the Father," through Jesus, paying reverence through the "Holy Cross" - the object on which the "son" (Jesus) was sacrificed. The enactment of the sacrifice in the passion play was vastly promoted among the sertanejo and Indigenous populations, which were also "sacrificed" and plundered. Inevitably, the cross became a symbol of faith and peace, mainly in the sertão region of the Brazilian Northeast, in a fervent manner in the prayers, in the residences and on the altars, chapels and crosses placed along on the roadside - as a consequence of some death - in front of some Indigenous villages, in the pilgrimage sites, in the rooms of the black quilombolas, ${ }^{33}$ and is still today protected nearly "in secret."

In the cities and villages, the main point of reference is the chapel and its cross. In front of these places; the cross indicates characteristics of the Catholic faith and other Christian attributes that console and redeem the "suffering beings," the "sinners," but always, based on supplication, sacrifice and the death of Christ, which for the penitent and unconsoled, buries the human suffering represented in their supplications, promises and penitence.

33 Translator's Note. Quilombolas are descendants of African slaves who escaped during the colonial period and formed refugee communities known as quilombos. 
The elements that compose the Christian sacrifice are widely enacted during Holy Week, such as the scorn, the imprisonment, the flagellation, the coronation of thorns, the agony, the burial and, finally, the resurrection of Christ, aspects, among others, which synthesize the quest or appeal for forgiveness, for peace, faith and the attainment of grace.

The Christian religiosity based on martyrdom and on the redemptive mission - of Jesus (LOYOLA, apude QUEIROZ, 1990: 109-120), is perceived in this region as an expression of a great sentiment of faith, which for the rural population of the sertão, is related to suffering, forgiveness, morality, the purification or purging of the body and the soul, through sacrifice, penitence, promises and pilgrimages.

According to Adalgisa Arantes (CAMPOS, 1993), this religious sentiment represented by the Holy Cross was assimilated by the popular imaginary and has its effects or its naturalization in the "materialization of suffering." It is in this sense that the strong popular tradition of enacting the drama of the Passion Play should be considered. That is, the enactment of the sacrifice, the suffering and the veneration of beatos such as Padre Cícero Romão, Beato Pedro Batista, Frei Damião, Madrinha Dodô and others of the region, who are representatives of this process, should be understood in this context.

These pilgrims also undertake, nearly simultaneously, a via cruz, also of penitence and devotion to Padre Cícero to Juazeiro do Norte, CE, which creates a symbiosis of veneration and devotion to Dodô, Pedro Batista and Padre Cícero, as well as to Beato Zé Vigário. The pilgrimages in the region are thus shared by Pedro Batista, ${ }^{34}$ which reveals the process of sacrifice, search for purification, pardon, consolation, the realization of ideas, the quest for health, peace, prosperity and simultaneous adoration or veneration for Padre Cícero Romão, Pedro Batista and Dodô. These actions are characterized by a predisposition to feelings of redemption and faith, which are given a foundation through the ordaining of cults to Christ, the Virgin Mary, and to the saints, to the "enchanted spirits" and to all the entities nourished by faith in the region. In this way an hierarchy is created in the region among saints, beatos and the "enchanted" entities [Christian and of indigenous, African and popular origin].

34 I will not refer here to Zé Vigário due to the complexity involved with these three personalities. He will be part of a broader work. 
In this sense, Jesus, the Christ, appears as a celestial mediator (within the celestial hierarchy), between the Virgin Mary (the mother) and God (the father) and the spiritual entities of the African and indigenous matrixes and their power. It is as if they were all part of a fraternal organization, that does not necessarily obey a defined hierarchy, but one that is expressed in a privileged form on the walls and altars of the large majority of houses of the sertão (of Alagoano, Baiano, Pernambucano, Sergipano, Cearense) and of the rest of the local population. This aspect becomes clear upon observing the daily life of these people, the religious associations related to faith and to superior "non-human" forces, but that emanate from their own humanity (charity) and from their idiosyncrasies. This is a unique experience generated by the simultaneous co-existence and cohabiting with historic and sociocultural processes in the region, which took place through the diffusion not solely of Christian faith, but of the simultaneous practice of various religious predicates promoted by hundreds of ethnicities: indigenous, African and European. This took place in such a way that, traditionally, the native experiences of faith, among other beliefs developed or introduced in Brazil, before during and after the colonial period, extrapolate a transparent temporality.

Represented by the pilgrims and penitents, those who are "paying for promises" made to a saint or beato and other religious groups, in the case of the faithful of the region from Alagoas, Bahia, Sergipe and Pernambuco ${ }^{35}$ it was possible to note in the sertanejos that assimilate this type of devotion that their religious experience is atemporarily indicated in their predilection for popularized faith, which is marked and executed by means of offerings, sacrifices, novenas, pilgrimages and the payment of promises, among other actions that mark certain beliefs.

The "promises," and even the pilgrimages, are part of the veneration and of the requests related to attained grace, or simply to the act of making an offering to please the protective saint, or, in the case of the black and indigenous populations, the offerings made to the protective entities, represented in the forests (hidden or not) in the temples, in the sacred places of indigenous rituals, in the umbanda terreiros, in the oratories and on the walls of the houses of countless sertanejos. To observe these practices is to pay attention to a re-evaluation of the religious experiences of each community 
and their individuals who express themselves in a particular form, which of course depends on the experiences of each person, of each community and its spiritual leaders who sustain and give continuity to the rituals, to the precepts of faith, whether it is a Christian belief or from other sources.

\section{Penitences and penitents}

The anthropological meaning of the pilgrimages is penitence: suffering conceived by the pilgrims as a legitimizing element, that is, the pilgrimage is a consequence of "suffering." In their ethnographic dimension, this element reflects the collective experience of the devotees, that is, of the "other." These experiences, inscribed in these people, are symbolic marks and obey an ethnographic and ethno-photographic model that is capable of reflecting the experience of this "other." In this sense, to research the pilgrimages from a theoretical perspective of community, ethnic belonging and reaffirmation also suggests a political proposal of legitimation of the pilgrims, beatas and beatos of Dodô and Pedro Batista. The pilgrimages of these groups, from a historic perspective - from Antonio Conselheiro and the saga of Canudos - and the formation of the pilgrimage houses by Father Ibiapina, generate questions and interpretations that, in a certain way, obey a proposal that sees them from a political perspective in the organization and legitimation of these groups.

In the path, considered here, from the time in which they leave their houses and village until they reach the cross, the final and sacred place of the pilgrimages, the pilgrims or Beatas of Dodô repeatedly chant and cite litanies venerating the Virgin Mary. The penitents (men), in secret, in the dark of the night, far from curious eyes, in front of or behind the chapel, in the cemetery, in front of a cross, or even in private, whip themselves with instruments of supplication, whips and leather. At times, the most orthodox use "iron blades" on the tip of a whip, which causes wounds and bleeding.

This self-flagellation, although it is now more limited, still takes place among the penitents of the region, mainly in the Alto Sertão of Alagoas and Bahia, where I registered some cases. I registered groups of penitents who conduct self-flagellation in Água Branca, Ouricuri, Pariconha and Inhapi, Alagoas; Pambú, Abaré and in Santa Brígida, Bahia. These are secret brotherhoods and "no one should know who whips themselves"; normally there are 
few people who know or identify who is or is not a penitent who practices self-flagellation. ${ }^{36}$

It appears that the brotherhood of the penitents in this region is related to the ideological principles of Beato Pedro Batista, which are similar to those of Conselheiro; for which reason they take pilgrimages to Santa Brígida and Juazeiro. At least that is what the penitents who are involved in this system demonstrate.

Nevertheless, the origin of these precepts appears to be prior to Pedro Batista. We can recall that the semiarid region, from Alagoas, Sergipe, Pernambuco and Bahia, the region of the Rio São Francisco, Ceará, Rio Grande do Norte and Piauí, was the scenery for messianic movements, also called "popular Catholicism," mainly since 1870, because of the terrible drought that scorched the region (MATOS, 2002: 219-235).

The transitional political and social situation between the last two decades of the Empire and the Republic were devastating. The hunger and the lack of water killed thousands of people; blacks, Indians and basically all sertanejos suffered from the drought. Marked by political abandonment and the control of the "coronels," this period is also marked by the diasporas of these populations who came to settle in other places, such as the countless descendants of quilombos and the indigenous who, only in the past two decades, have been recognized on the political scene because of the enactment of affirmative action policies for the restitution of land and granting of other constitutionally guaranteed rights.

With the extinction of indigenous villages between the 18th and 19th centuries (in Alagoas, since 1872), the Indians lost their unoccupied lands to the federal government. Meanwhile, blacks were freed from slavery with the abolition law of 1888, but not from abandonment, joining the Indians and the thousands of previously freed slaves who did not have lands, because they gained their freedom before the Abolition Law. For these reasons, the last two decades of the $19^{\text {th }}$ century were terribly difficult for the people of the Northeast.

36 Among the Jeripankó Indians of Pariconha, Alagoas, there is a very strong taboo against seeing the face of a penitent. During Holy Week, when they pass through the village, these Indians say that "everyone closes the doors of their houses to not see who they are." When they self-flagellate, they do so "until they bleed." There is always a person among them who helps to clean the wounds with an herb wash. The Indians and any other group that practices this precept are very reserved when they are approached about this issue, they do not like to speak about it. 
In this calamitous scenario, figures such as that of Padre Ibiapina and Beato Conselheiro were essential. They are the ones, according to Matos (2002), mainly Padre Ibiapina, who founded the "Charity Houses" and points of pilgrimages. In the mid-20 ${ }^{\text {th }}$ century, Pedro Batista and Madrinha Dodô continued the methods of the earlier beatos. The pilgrimage houses are found throughout some regions of the Northeast and are also called "Charity Houses." In addition to providing food and drink to thousands of people ravished by drought, they also provided a structure for survival, such as shelter, healthcare, vegetable gardens and fields to plant to sustain those fleeing drought (MATOS, 2002: 222).

While Conselheiro and other beatos made prophecies related to morals, hope, faith, chastity, humility, repentance and penitence (QUEIROZ, 1976: 226-227), among other principles of medieval origins, the people assimilated these practices linked to "forgiveness" and "attaining grace," normally in efforts to cure disease and find relief from the living conditions of that time.

In a certain way, the misery in the region was resolved on one hand by the pilgrimage houses, shelters for people uprooted by the drought, an in parallel by another, by the politicians and coronels of the region and support from the Church or the rise of a "messiah" or a "spiritual guide," as in the case of the beatos briefly described here.

This practice is still common today and figures such as Padre Cícero and later Beato Pedro Batista, Madrinha Dodô and Frei Damião, Zé Vigário and others, contribute to the continuation of the precepts of Catholicism, understood as "messianism" or "Popular Catholicism" (QUEIROZ, 1976).

Fruits of the 2oth century, these "new messiahs" also contribute to providing a reciprocal element of well-being for the sertaneja populations - corporal health - in addition to spiritual health. They conduct penitence and pilgrimages, chant blessings and pray with their rosaries for the souls of purgatory, actions that make viable spiritual defense and the strengthening of their faith and the cure of the body. Their conditions require considerable collective strength to organize the economic means to realize the pilgrimages and the payment of promises.

Despite this close relationship between faith, favors, and politics, these movements cannot be analyzed solely through these paradigms. The religious movements, or perhaps messianic movements, in the region have undergone complex changes, but maintain many elements of that time, and are 
still related to local politicians, merchants and large landowners.

The pilgrimages are socially organized through kinship ties and affinities. This social base, both for the individual and for the communities, cause them to unite for a certain purpose, whether for collective activities related to daily work, rituals of promises or pilgrimages, or even, solely to worship their favorite saint or beatos, aspects that I observed during the visits to the indigenous villages, quilombo communities and groups of rural workers or peasants during my field work among the Indians of the Alto Sertão of Alagoas between 1999 and 2010, and more specifically, during my recent field work with the pilgrimages in Água Branca, AL and Santa Brígida, BA in 2012. This entire process is ripe with meaning concerning the relationship between these groups and their religious and interpersonal functions, in the social interactions and their particularities, aspects that guarantee the continuity and the sense of belonging to a socially and culturally organized group.

In this process, the relationships are personal, varied, direct and effective in the sense that they relate to the power of curing the body and spiritual peace and the search for solutions to economic, social and emotional problems often caused by the distancing created in diasporas taken to search for survival in other locations. These religious processes are used to venerate the beatos and patron saints and offer retribution for "attained grace" and strive for their religious integrity, or that is, faith and maintain the religious principles as a form, not only of respect, but mainly of devotion and appreciation.

In this complex universe, the pilgrimages, the devotion to Padre Cícero, to Beata Dodô and to Beato Pedro Batista, the respect for the penitents and to the saints of the Christian faith, denote meanings that are particular to each one of them.

The penitences and promises are conceived, organized and executed as a type of a patrimony (of the groups) of self-inscription and alterity. The pilgrimages, as a product of Christian faith, were assimilated by a continuous process of colonial imposition that from generation to generation gradually took on different forms of interaction among the sertanejos and the majority of society at large. These forms were gradually naturalized and became hybrids, to the point that, in a superficial observation, the elements of one and another culture appear to be completely merged. Nevertheless, differences between each group of penitents and pilgrims exist that indicate an appropriation of these elements as part of their local or native experiences in the region, whether 
those of Indigenous peoples, quilombolas, sertanejos or rural workers.

These differences are marked in spatial terms (geographic, socio-cultural and ethnic boundaries) and temporal ones, and above all, in the types of situations shared and experienced with other elements and other social actors. These are inserted in each group in some way, establishing different degrees of relationships, mainly of economic solidarity, which, little by little, were introduced in these contemporary groups and that are visible in the ways that they organize themselves in different contexts to achieve the ultimate meaning of the penitences. This involves the strengthening of faith, appreciation for the attainment of grace and veneration of the saints and beatos, which takes place through an internal force of local self-identification linked to their spiritual forces and to purification of the body.

An absence or lack of thanks to the spiritual entities, according to the faithful, saints and beatos, would trigger a lack of protection that would affect not only the individual, but the entire community or family group. In the search for this alterity, efforts are made to revive "experiences of faith." Thus, each group of penitents or pilgrims is divided into a group and subgroup that expresses greater or lesser yearning for faith and devotion to the saints and beatos. This involves cultural criteria and regular practices that are selfregulated, which simultaneously indicate social position (within each group of pilgrims and penitents), faith and spiritual congregation.

The penitents, pilgrimages and promises are consecrated in various moments of song, litanies to the Virgin Mary and to the Crucified Christ in a great collective and community representation. In these ritual spaces, candles are lit; at some moments, absolute silence is necessary, at others, the music with a small band and fireworks are offered; the faithful present themselves solemnly as part of this entire ceremony. This is an essential contribution to the realization of the penitent ritual. That is, the worshipers request and offer retribution for the grace attained; the local community adheres, takes knowledge of and during the via cruz (at the place of departure and the final destination) various people (or local residents) adhere to the "pilgrimage." In front of the Catholic church, they light fireworks and pay reverence to the saint or beato and return to the house of the "payer" of the promise, where they pray with rosaries, light fireworks and end with prayers and litanies of devotion. This is a private/particular moment, which normally cannot be measured or compared. 
During the trajectory, the pilgrims sing of the link that unites them in pilgrimage: there is "a God who walked, a God who walked." Dressed in white, the penitents trace the route of the "suffering of carrying the cross," the "burden of life," and at the cross, the "final destination" of the penitence, give thanks: "offer this blessing to the Lord who is on the Cross, at the will of my godfather and of the Heart of Jesus". They kiss the Cross.

The imagetic narratives of the religious objects (Catholic saints and other entities of Afro-indigenous matrixes) mixed with family portraits and copies of romantic paintings exhibited on the walls of homes, obey a logic of presentation (some on walls, others on an altar) which varies from anaesthetic decorative narrative to another of religiosity. When these aspects are reconfigured they give shape to a representation that goes beyond merely decorative elements in the homes, to guarantee social and religious values that are resignified and shared with visitors, relatives and friends. Ripe with socio-cultural subjectivities, these elements are used in the payment of a promise. For example, during a pilgrimage, they are taken with devotion to the locations of the pilgrimage or viacruz. By occupying their place on the walls, these images are objects of observation, interpretation. They may also have a socio-decorative value, while at other times they are revered (at the novenas, on the saint's day, etc.), which guarantees the sacred value and the interactions between one function and another.

During the pilgrimages or on each special day of worship to a saint or even when paying a promise, for example, if the dancers of São Gonçalo are called on, or a small band is hired, the reverence of the musicians is directed to the altar and not to the "payer" or "owner" of the promise or "patron" of the novena, who normally remains nearly unnoticed. In these types of performances, a spontaneous relationship is noticed that is marked by an experience, an appropriation of the ritual elements and not only a mise-en-scène of the people photographed or filmed who behave, in most cases, "naturally" in front of the camera.

At these events at which the penitents participate, the participation of couples who are "not married, who are living together without the grace of God; the impure, the profane, gamblers and sinners," are usually not permitted, according to the penitents and pilgrims of Dodô. In this way the religious substrate present in the daily life of the penitents and pilgrims comes from a popular tradition of the ritualistic payment of promises, which 

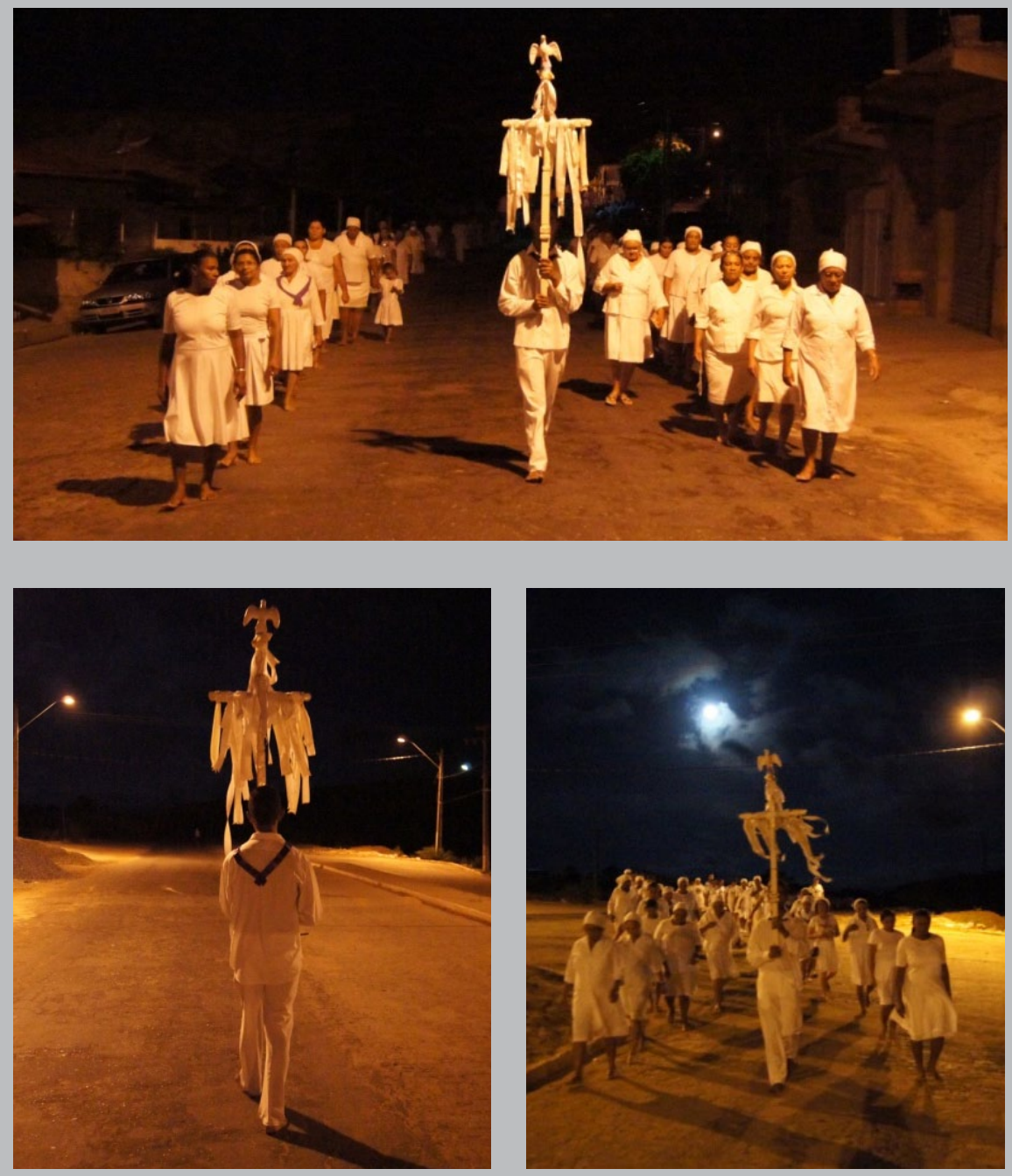

Image 33, 34, 35

Before the image of the Lord of the Good Death and of the Virgin Mary, the pilgrims and penitents ask for piety, purification of the soul and eternal peace. With this premise, dressed in white and barefoot, they pass silently through the streets of the city, first to the cemetery in which are the mortal remains of Madrinha Dodô and Pedro Batista, and then, before both of their tombstones, and chant loudly "eternal peace," and so on, until the next pilgrimage. In the vigils to the Dead Lord the practice of the cults of adoration of the penitents are part of the rituals of devotion to Santa Cruz and to "Good Deaath" and to the suffering of the Virgin Mary, the mother of Jesus, for seeing her son suffer mercilessly. Aspects related to Pedro Batista and to Madrinha Dodô juxtapose, the first as Jesus Christ and the second as the Virgin Mary. 
normally relate morally with the spiritual entities, through faith, prayer and penitence. "The pilgrims come from that ancient people, from the cattle corals, from the indigenous villages of the regions of the São Francisco [River], from the waterfalls, the guardians of the enchantments," as they themselves affirm. During the passage, which also represents geographic - territorial narratives that in past times they passed through to pay reverence to their "dead" buried in the cemeteries and along the roadside, they recite countless Our Fathers, Ave-Marias [Hail Mary's] and Hail Holy Queens, evocations that indicate the strong influence and appropriation of the rituals of the orthodox penitents, whose prayers usually conclude at the crosses or cemeteries, without necessarily returning to the chapel or church.

Nevertheless, the reflection here revolves around the circulation of their rituals represented in the organization of the penitences and pilgrimages, in the images placed on the walls of the houses transformed into altars, in oratories, even the way that they are presented in the sacred spaces, like churches, cemeteries, at crosses, residential altars and even in the form of serving food to the hosts of the festivals, to the penitents or pilgrims, or even to the musicians who play Zabumba, and dancers who are convoked for the realization of these collective rituals.

These arrangements, it is possible to note, go beyond abstract or symbolic motifs. In this sense, their force originates in aspects of common reality, or at least, comes from it, like, for example, the liberation from a malign act that by chance comes to affect a member of a community or family.

In this unique manner, the act of living together and interacting in these communities, historically, is present in an intimate manner, in various types of constructions of reality and in the spaces (rural, urban, ritual, religious) in which these events take place. This indicates a series of social values within and among the group and acts among the collective and of course also on the individual. In the case of the penitences and even of the promises, both those that are public and also those that are partially "secret," as in the case of the pilgrimages, prayers and "orientations in trance," pass through a series of processes that trigger the identity of the archetype of the saint (or beato) and the form of inter-relating with these figures.

These inter-relations, in a symbolic manner, cause a change in the nature, for example, of the demands or even individual promises, causing them to become collective and everyone can participate, even people from 
Returning from the cemetery to the Church, as indicated in photos $36-38$ at daybreak, the "body of Christ" is placed before the church, the liturgy for resurrection

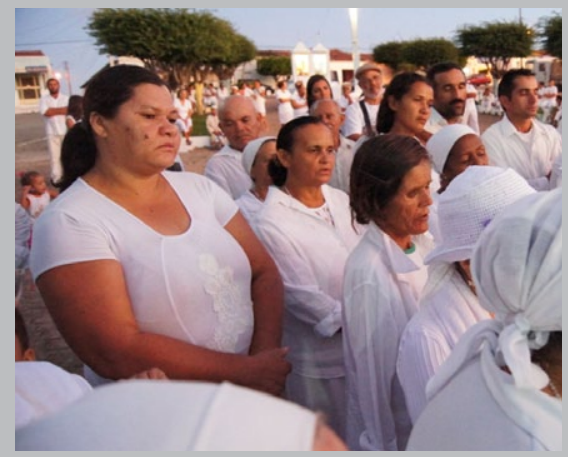

is conducted outside the church, and the image of Christ receives the first sunlight, thus symbolizing the rebirth of Christ.

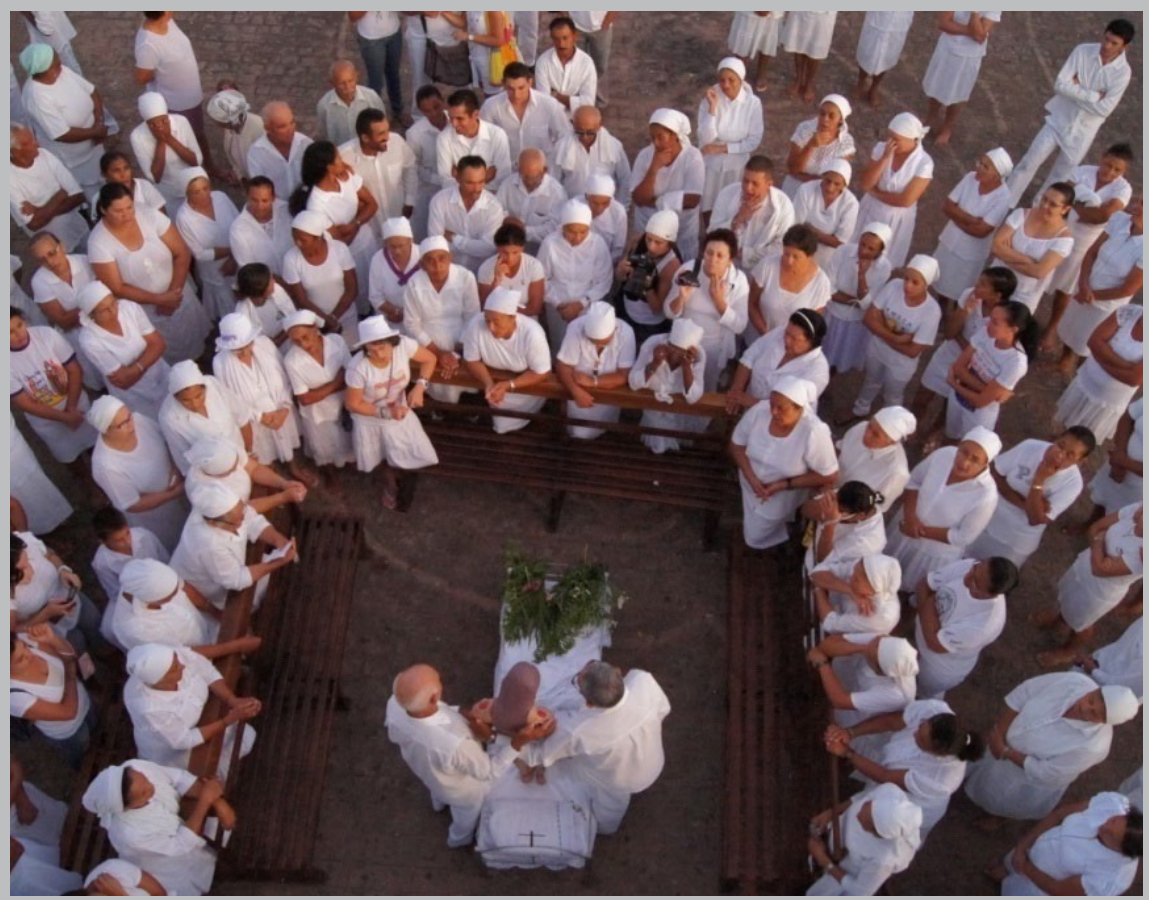

Images 36, 37 and 38. April 2012. "Passage" of Christ, from death until life. After the peregrination to the cemetery, a beato, always at the front of the pilgrimage, carries the Holy Cross and on top, the dove that symbolizes the Holy Spirit, with which, in front of the cemetery, they call for the eternal peace of the souls.

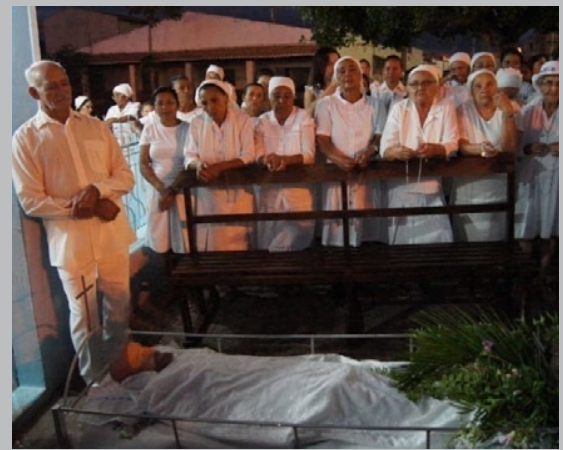


other realities, who can also join the group, which in this way attributes responsibility to the community or to the group to continue its constantly shifting trajectory. In this broad sense, the pilgrimages, penitences and promises are part of a space that according to the pilgrims "makes ties, that communicates," that incorporates the sacred elements and also connects the subjects with the external and cosmological world, with the material and immaterial. This broad and complex universe is reconfigured "in an orchestral form", as they say, although it is mediated based on a common element: the establishment and strengthening of faith, to "not let the customs die," as the pilgrims affirm.

These are aspects of multiple cultural (re)apresentations that necessarily lead us to aesthetic, socio-religious interpretations and dispositions mediated by visual portraits (re)produced by memory (ECKERT \&ROCHA, 2004). These narratives, once ethnographed, coming from native experiences, extend beyond this frontier at which the conflicts are translated, interactions between time and collective memory, between the subjects studied (products of knowledge) and the outside world. In this study, which is ongoing, it is important to highlight that investigating socio-cultural phenomenon like those represented here by pilgrims and penitents of Madrinha Dodô, through the duration of time lived and time thought (ECKERT and ROCHA, 2000), involves not only remembering or reconstituting these temporal experiences of human memory, but, above all, passing along the transformation and ruptures imposed by the duration of time that modifies and reorganizes reality and fixes in memory - in the case of the pilgrims and penitents of Dodô, Pedro Batista, Padre Cícero - other times, perhaps those still to come, but which however, would be as revealing as those that were described in these few lines, revealed by means of the extraordinary mythic memory of the beatas and beatos of Dodô and their lived and experienced time.

\section{References}

ACHUTTI, Luiz Eduardo Robinson. 1997. Fotoetnografia: um estudo de antropologia visual sobre o cotidiano, lixo e trabalho. Porto Alegre: Palmarinca.

ACHUTTI, Luiz Eduardo Robinson. 2004. "Fotos e palavras, do campo aos livros”. In: Portal da fotoetnografia do Grupo de Pesquisa Fotografia e 
Fotoetnografia: "Arte e antropologia”. Disponível em: http://www6.ufrgs. br/fotoetnografia/ textos/texto achutti.pdf . Acesso em 19 ago. 2012.

CAMPOS, Adalgiza Arantes. s.d "Semana Santa na América portuguesa: pompa e ritos e iconografia”. Disponível em: http://www.upo-es//depa/ webdhumanas/areas/arte/actas/3cibi/documentos/o95f.pdf. Acesso em 15 jul. 2009.

CASTRO, Eduardo Viveiros de. 2002. A inconstância da alma selvagem. São Paulo: Cosac \&Naify.

DARBON, Sébastien. 1998. “O etnólogo e suas imagens”. In: Etienne Samain (org.), O fotográfico. São Paulo: Hucitec. pp.101-111.

ECKERT, Cornelia; ROCHA, Ana Luiza Carvalho. 200o. "A memória como espaçofantástico”. Iluminuras: Série do Banco de Imagens e Efeitos Visuais, 1(1). Porto Alegre: Banco de Imagens e Efeitos Visuais; PPGAS/UFRGS. Disponível em: <.http://seer.ufrgs.br/iluminuras/issue/view/761. Acesso em 22 maio 2012.

ECKERT, Cornelia; ROCHA, Ana Luiza Carvalho. 2004. “O antropólogo na figura do narrador". Revista Habitus, 1(2): 395-420.

GEERTZ, Clifford. 2003. O saber local: novos ensaios em antropologia interpretativa. 6. ed. Petrópolis: Vozes.

GONZALES, Olegário Miguez. 2004. "Bem-aventurança em Santa Brígida”: uma comunidade sob a orientação de Pedro Batista. Dissertação (Mestrado em História). Universidade Federal da Bahia, Salvador,UFBA.

LANGDON, Esther, Jean. 1996. "A fixação da narrativa: do mito para a poética de literatura oral”. In: Eckert \& Rocha (orgs.), Revista Horizontes Antropológicos, 5(12): 13-37.

LARAIA, Roque. 1997. "Jardim do Éden revisitado”. Revista de Antropologia, 40: 149-164. Disponível em: <http://pt.scribd.com/doc/536896o8/LARAIARoque-Jardim-do-Eden-revisitado> Acesso em 22 maio 2012.

LE BRETON, David. 2007. El sabor del mundo - uma antropología de los sentidos. Buenos Aires: Ediciones Nueva Visión.

LOYOLA, Santo Inácio de. 1990. Exercícios espirituais. Tradução de Joaquim F. Pereira. São Paulo: Loyola.

MATOS, Henrique Cristiano José. 2002. Nossa história: 500 anos de presença da Igreja Católica no Brasil. Tomo 2: Período Imperial e transição republicana. São Paulo: Paulinas.

MURA, Claudia. 2012. “'Todo mistério tem dono!': ritual, política e tradição 
de conhecimento entre os Pankararu. Tese (Doutorado) - UFRJ/ Museu

Nacional. Programa de Pós Graduação em Antropologia Social.

QUIEROZ, Maria Isaura Pereira. 1976. O messianismo no Brasil e no mundo. São

Paulo: Alfa Omega.

SOUZA, Maíra Salles de; OLIVEIRA, Tereza Cristina de; GOTTCHAL, Carlota.

s/d. "Irmandade da Nossa Senhora da Boa Morte e o marketing cultura".

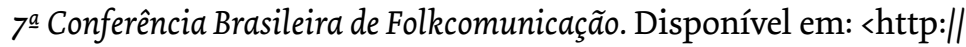

encipecom.metodista.br/mediawiki/images/5/5d/Irmandade_da_Nossa_

Senhora_da_Boa_Morte_e_o.pdf $>$. Acesso em 14 set. 2009.

RICOEUR, Paul. 2002, "Definición de la memoria desde unpunto de vista

filosófico". Academia Universal de las Culturas, ¿Por qué recordar?

Barcelona: Granica.

RIEDL, TITUS. 2007. Viva a Boa Morte: memórias de comunidade romeira. Tese

(Doutorado em Sociologia). Universidade Federal do Ceará.

ROCHA, Ewelter de Siqueira e 2012. Vestígios do sagrado: uma etnografia sobre

formas e silêncios. Tese (Doutorado em Antropologia Social). Faculdade de

Filosofia, Letras e Ciências Humanas, Universidade de São Paulo, USP.

THEIJE, Marjo de; JACOBS, Els. 2003. "Gênero e aparições marianas no Brasil contemporâneo". In: Carlos Alberto Steil, Cecília Loreto Mariz e Reesink

(orgs.), Maria entre os vivos: reflexão e etnografias sobre aparições marianas no

Brasil. Porto Alegre: Editora da UFRGS. pp. 37-49.

TURNER, V. 1974. O processo ritual. Petrópolis: Vozes.

TURNER, V. 2005. Floresta de símbolos. Niterói: Eduff.

ZUMTHOR, Paul. 1997. Introdução à poesia oral. São Paulo: Hucitec.

\section{About the author}

\section{Siloé Soares de Amorim}

Dr. in Social Anthropology from the Federal University at Rio Grande do Sul

- UFRGS. Professor of Anthropology at the Social Sciences Institute of the Federal University of Alagoas, Maceió, AL

Address: Trav. Humberto Mendes, n. 85 - Jaraguá, Maceió, AL - CEP 57020-580

Email: siloe.amorim@gmail.com

Recived April 30, approved June 20 